\title{
Biomedical Applications of Layer-by-Layer Assembly: From Biomimetics to Tissue Engineering**
}

\author{
By Zhiyong Tang, Ying Wang, Paul Podsiadlo, \\ and Nicholas A. Kotov*
}

The design of advanced, nanostructured materials at the molecular level is of tremendous interest for the scientific and engineering communities because of the broad application of these materials in the biomedical field. Among the available techniques, the layer-by-layer assembly

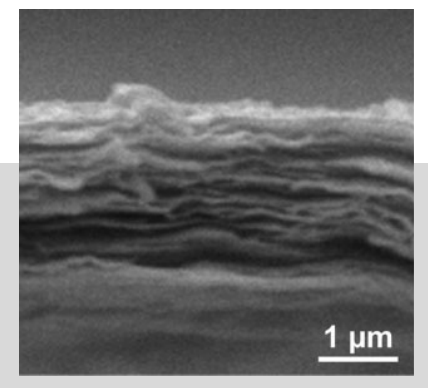
method introduced by Decher and co-workers in 1992 has attracted extensive attention because it possesses extraordinary advantages for biomedical applications: ease of preparation, versatility, capability of incorporating high loadings of different types of biomolecules in the films, fine control over the materials' structure, and robustness of the products under ambient and physiological conditions. In this context, a systematic review of current research on biomedical applications of layer-by-layer assembly is presented. The structure and bioactivity of biomolecules in thin films fabricated by layer-by-layer assembly are introduced. The applications of layer-bylayer assembly in biomimetics, biosensors, drug delivery, protein and cell adhesion, mediation of cellular functions, and implantable materials are addressed. Future developments in the field of biomedical applications of layer-by-layer assembly are also discussed.

\section{Introduction}

In the second half of the 20th century, scientists have been attracted to the design of thin solid films at the molecular level because of their potential for applications in the fields of biology and medicine. Two techniques dominated research in this area: Langmuir-Blodgett deposition ${ }^{[1,2]}$ and self-assembled monolayers (SAMs). ${ }^{[3-5]}$

Both Langmuir-Blodgett deposition, invented by Langmuir $^{[6]}$ and Blodgett, ${ }^{[7]}$ and the SAM technique, developed by

[*] Prof. N. A. Kotov, Dr. Z. Tang, Y. Wang, P. Podsiadlo Department of Chemical Engineering,

Department of Material Science and Engineering, and

Department of Biomedical Engineering

University of Michigan

Ann Arbor, MI 48109-2136 (USA)

E-mail: kotov@umich.edu

[**] This work was supported by NSF-CAREER, NSF-Biophotonics, NIH, NASA, AFOSR, and OCAST.
Nuzzo and Allara, ${ }^{[8]}$ and by Whitesides and co-workers, ${ }^{[9]}$ have shown remarkable capability for the immobilization of proteins and cells and subsequent application in biocatalysis, drug delivery, and tissue engineering. ${ }^{[3,4,10-12]}$ However, several intrinsic disadvantages of both methods limit their application in the field of biology. For Langmuir-Blodgett deposition, the drawbacks are expensive instrumentation and long fabrication periods for preparation of the biomolecule films, limited types of biomolecules that can be embedded in the film (Langmuir-Blodgett deposition requires the assembly components to be amphiphilic), and the considerable instability of biomolecules resulting from weak physical attraction inside the films. For SAMs, the disadvantages are low loading of biological components in the films because of their monolayer nature, a limited number of substrate types, since SAMs are only fabricated by the adsorption of thiols onto noble metal surfaces or by silanes onto silica surfaces, and the limited stability of films under ambient and physiological conditions.

An alternative to Langmuir-Blodgett deposition and SAMs is layer-by-layer (LBL) assembly, introduced by Decher, 
Hong, and co-workers in $1992^{[13]}$ for preparing structure-controlled thin films for biological applications. The preparation principles and procedures of LBL assembly are quite simple, shown in Figure $1 .^{[14]}$ It is known that many surfaces, such as metals, silicones, and glasses, have net negative charges in solution because of surface oxidation and hydrolysis. When immersed in a solution of positively charged polyelectrolyte, such as poly(diallyldimethylammonium chloride) (PDDA), poly(allylamine hydrochloride) (PAH), or polyethyleneimine (PEI), and subsequently rinsed by pure water (the aim of rinsing is the removal of loosely adsorbed polyelectrolyte from the substrate), the net charge of the substrate's surface becomes positive because of the adsorption and overcompensation of polyelectrolyte with opposite charges (middle image in Fig. 1B). Subsequent execution of the analogous procedure with a negatively charged polyelectrolyte solution, such as poly(styrene
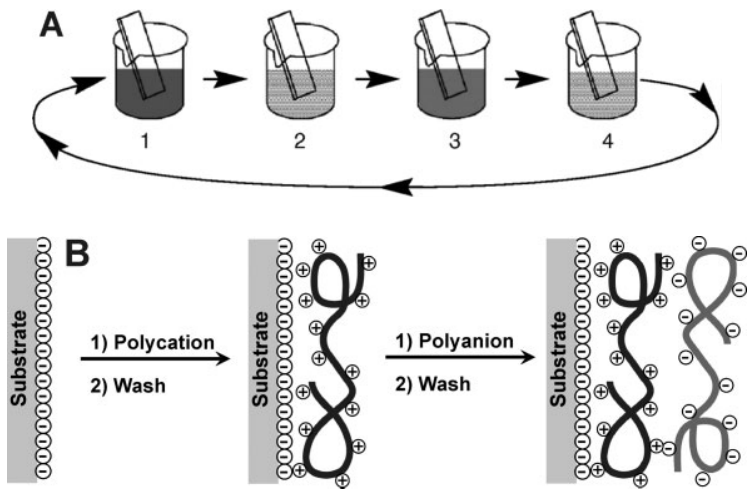

Figure 1. A) Scheme of the LBL film-deposition process using glass slides and beakers. Steps 1 and 3 represent the adsorption of a polyanion and polycation, respectively, and steps 2 and 4 are washing steps. The four steps are the basic buildup sequence for the simplest film architecture, $(A / B)_{n}$. The construction of more-complex film architectures requires only additional beakers and a different deposition sequence. B) Simplified molecular picture of the first two adsorption steps, depicting film deposition starting with a negatively charged substrate. The polyion conformation and layer interpenetration are an idealization of the surface-charge reversal with each adsorption step. Reproduced with permission from [14]. Copyright 1997 American Association for the Advancement of Science. sulfonate) (PSS), poly(vinyl sulfate), or poly(acrylic acid) (PAA), leads to the reversal of net charge on the substrate, bringing it back to the starting point (right image in Fig. 1B). As a result, a double polyelectrolyte layer (bilayer) is built up on the substrate. With such cyclic depositions, one can achieve multilayer films on the substrates with desired structures and thicknesses (Fig. 1A). Since the thickness of a single bilayer of polyelectrolyte is typically below $1 \mathrm{~nm}$, the $\mathrm{LBL}$ technique allows for nanometer-scale control of the thickness of thin films. ${ }^{[14,15]}$ In comparison with the SAM technique, the multilayer structure of LBL-deposited films allows for much higher loadings of biologically interesting species, while in comparison with the Langmuir-Blodgett technique it is not only much simpler and faster, but also results in more stable films.

The LBL technique is not only applicable for polyelectrolyte/polyelectrolyte systems. Almost any type of charged species, including inorganic molecular clusters, ${ }^{[16,17]}$ nanoparticles (NPs) ${ }^{[18]}$ nanotubes and nanowires, ${ }^{[19,20]}$ nanoplates, ${ }^{[21,22]}$ organic dyes, ${ }^{[23]}$ dendrimers, ${ }^{[24]}$ porphyrins, ${ }^{[25]}$ biological polysaccharides, ${ }^{[26,27]}$ polypeptides, ${ }^{[28,29]}$ nucleic acids and DNA, ${ }^{[30]}$ proteins, ${ }^{[31-34]}$ and viruses, ${ }^{[35]}$ can be successfully used as components to prepare LBL films. The universality of the LBL process has catalyzed the rapid development of biomedical applications of polyelectrolyte multilayers and related nanostructured organic-inorganic composites. This translates into an exceptionally wide variety of structural characteristics and, thus, functional properties.

The formation forces of LBL films are not only limited to electrostatic interactions. Assemblies based on hydrogen bonding, ${ }^{[36]}$ charge transfer, ${ }^{[37]}$ covalent bonding, ${ }^{[38,39]}$ biological recognition, ${ }^{[40]}$ and hydrophobic interactions ${ }^{[41,42]}$ have also been investigated. Besides charged inorganic substrates, hydrophobic polymer surfaces have also been shown to provide good scaffolds for LBL growth based upon hydrophobic interactions. ${ }^{[43]}$ Overall, availability of a wide spectrum of fabrication components, variety of substrates, and versatility of assembly methods dramatically enriches the biological applications of LBL films. Moreover, multiple interactions in the LBL films can potentially increase the stability of films while being exposed to physiological or even harsh conditions.

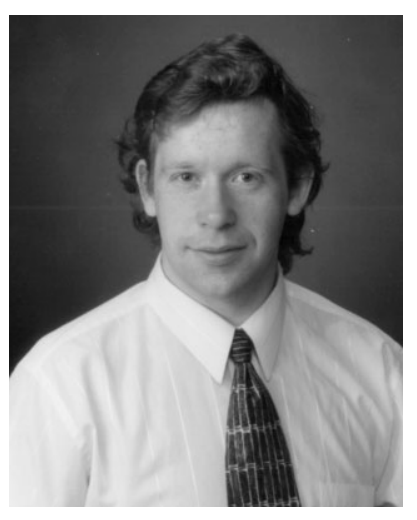

Nicholas A. Kotov was born in Moscow (Russia) in 1965. He graduated from the Chemistry Department of Moscow State University in 1987, where he subsequently received his Ph.D. degree in 1990 (advisor: M. Kuzmin). After that, he worked as a post-doctoral associate at Syracuse University in the group of J. Fendler. He moved to the Oklahoma State University to take a position of Assistant Professor in 1996, where he was promoted to the rank of Associate Professor in 2001. Currently, he is an Associate Professor at the Department of Chemical Engineering of the University of Michigan in Ann Arbor, sharing this appointment with the Departments of Materials Science and Biomedical Engineering. His research interests in the field of nanostructured materials include synthesis of new nanocolloids, their organization in functional assemblies, layer-by-layer assembled nanocomposites, computer modeling of self-organization processes, ultrastrong materials from organized nanocolloids, nanowire-based nanodevices, biosensing applications of nanomaterials, interfacing nanomaterials with living cells, and cancer treatment and diagnostics with nanoparticles. 
Owing to their simplicity, versatility, and robustness, an increasing number of research groups are becoming involved in LBL research. A review of the current literature reveals that there were around 600 articles dealing with LBL films published in internationally distributed journals in 2004. ${ }^{\text {[4] }}$ Although the application of LBL films has been reviewed in several journals ${ }^{[14,45-48]}$ and books, ${ }^{[49,50]}$ reviews that include the biological field are rare. ${ }^{[51-53]}$ In this Review, we attempt to provide the readers with a full survey of the biological applications of LBL films grown on 2D flat substrates. It should be noted that LBL films can actually be prepared on substrates of any shape, including $1 \mathrm{D}$ tubes ${ }^{[54,55]}$ or $3 \mathrm{D}$ colloids, which result in microcapsules. ${ }^{[56,57]}$ Since the biological applications of microcapsules fabricated by LBL deposition have been extensively discussed and reviewed, ${ }^{[58,59]}$ this paper will focus only on more-conventional LBL films.

\section{Structure and Bioactivity of Biomolecules in LBL Films}

The formation of LBL films is usually based on a multiplicity of intermolecular interactions where the cooperative effect of multipoint attractions may play the most important role. As such, several questions concerning application of LBL films in biology emerge: Will different types of biomolecules and biologically important entities, such as vesicles, retain their structure and bioactivity after incorporation into multilayer films? Can we maintain or even improve the biological functions of the films by taking advantage of LBL methods? This section offers some answers to these questions.

\subsection{Lipid Vesicles}

It is known that lipid vesicles are composed of low-molecular-weight amphiphilic organic molecules. Embedding vesicles into multilayers using strong electrostatic interactions inevitably results in the rupture and fusion of the spherical structures of the vesicles. ${ }^{[60]}$ In order to enhance the mechanical properties, Katagiri et al. ${ }^{[61,62]}$ stabilized vesicles by designing a polymerized silica shell at the vesicle surface by self-condensation of triethoxysilyl groups in water, and Michel et al. ${ }^{[63,64]}$ rigidified vesicles by adsorbing one layer of polyelectrolyte with opposite charge onto the surface of vesicles before performing LBL deposition. Analysis using atomic force microscopy (AFM) confirmed that the vesicles prepared from both methods remained intact after being immobilized in the multilayer films and could be used as reservoirs for drug delivery or biomolecular reactors.

\subsection{Polypeptides}

The secondary structures of polypeptides embedded in LBL films have been explored by several groups. ${ }^{[28,29,65-67]}$ Muel- ler ${ }^{[28]}$ and Boulmedais et al. ${ }^{[29]}$ showed that both poly(L-lysine) (PLL) and poly(L-glutamic acid) (PLGA) underwent a transition from random coils to $\alpha$-helixes when adsorbed from solution onto the partner PDDA, PAH, or poly(vinyl sulfate) layer because of the lower local $\mathrm{pH}$ in the LBL film. Interestingly, the LBL films from the alternative assembly of PLL and PLGA exhibited extensive $\beta$-structure formation, whereas such $\beta$-structure elements could not be detected in similar LBL films made of PLL and poly(L-aspartic acid) (PLAA). ${ }^{[66]}$ The authors concluded that interactions between PLGA and PLL chains induced the formation of $\beta$-sheets where the positive charges of PLL were stabilized by the negative charges of the carbonyl groups of PLGA. ${ }^{[6]}$ On the other hand, Haynie et al. ${ }^{[67]}$ found that the deposition of PLGA and PLL per adsorption step scaled with the average secondary structure content in the solution, whether $\alpha$-helix or $\beta$-sheet. In other words, the secondary structures of polypeptides immobilized in the LBL films did not change compared with those in solution. The difference in the observed results reflects the fact that the interactions between polypeptides and polyelectrolytes in the LBL films, including hydrogen bonding, hydrophobic forces, and electrostatic attraction, are multifold and complex.

\subsection{Nucleic Acids and DNA}

Sukhorukov et al. ${ }^{[68]}$ and Montrel et al. ${ }^{[69]}$ fabricated DNAbased LBL films by alternative assembly of anionic DNA strands and cationic polyelectrolytes such as PEI, PLL, and polyallylamine, and studied the DNA structures in the films by IR, UV-vis, and circular dichroism (CD) spectroscopy. The authors proved that formation forces in the films originated from the electrostatic attraction between the negatively charged $\mathrm{PO}_{2}^{-}$groups of DNA and the positively charged groups on the polycations. The DNA conserved its double-helical structure in all of the films. Water molecules were found to easily penetrate into all types of films and bind with DNA hydration centers (phosphate groups). In contrast to usual DNA films, the hydration in the LBL films did not initiate the B-to-A conformational transition of the double helix. More importantly, the DNA-containing films retained good bioactivity and exhibited remarkable binding abilities with different DNA-intercalated molecules, including antitumor drugs.

\subsection{Proteins}

One of the main trends in the biological applications of LBL assembly is embedding bioactive proteins into thin films and utilizing their unique functions in opto-electrical devices, sensors, drug delivery, cell seeding and growth, tissue engineering, and implantable materials. In the following sections, with the description of specific applications we will discuss the stability and bioactivity of different types of proteins in LBL films. 
In this section, one example is illustrated in order to evaluate the stability and activity of proteins in films. A multilayer film containing the enzyme glucose oxidase (GOD) was prepared by alternative adsorption of anionic GOD and cationic PDDA or PEI. In order to test the bioactivity of GOD in the LBL films, Onda et al. ${ }^{[0]}$ designed a sequential enzymatic reaction by immersing the GOD films into solutions of D-glucose, peroxidase (POD), and DA67 dye mixtures. As shown in Figure 2A, GOD in the film catalytically converts n-glucose and $\mathrm{O}_{2}$ into D-glucono- $\delta$-lactone and $\mathrm{H}_{2} \mathrm{O}_{2}$. POD subsequently oxidizes DA67 dye (an indicator) using $\mathrm{H}_{2} \mathrm{O}_{2}$ as the oxidant. Since the oxidized product of DA67 has a large molar extinction coefficient of $90000 \mathrm{M}^{-1} \mathrm{~cm}^{-1}$ at $665 \mathrm{~nm}$, the enzymatic reaction and activity of GOD enzymes in the films could be followed by monitoring the absorbance spectrum. Compared with native GOD in solution, the activity of GOD enzymes in the films was reduced by about $20 \%$, indicating that the immobilization process did not cause significant denaturation of enzymes. The enzymatic activity of the GOD film was maintained for 14 weeks when stored in buffer and in air at $4{ }^{\circ} \mathrm{C}$. Notably, the GOD enzymes showed a tremendous improvement in environmental tolerance after being embedded in the films. For example, immediately after incubation at $50{ }^{\circ} \mathrm{C}$ the relative activity of aqueous GOD decreased to almost zero, whereas that of GOD in the film maintained $90 \%$ of its activity (Fig. 2B). The pH dependence of activity also showed that GOD in the films exhibited better stability in alkaline media compared with aqueous GOD (Fig. 2C). Indeed, the enhancement in the stability was almost the same for GOD enzymes either encapsulated by a silica gel matrix or immobilized inside a LBL multilayer (Fig. 2C). The reader should keep in mind that in comparison to LBL both the amount encapsulated and the enzyme structure in the sol-gel matrix are very difficult to control. As an assembly technique
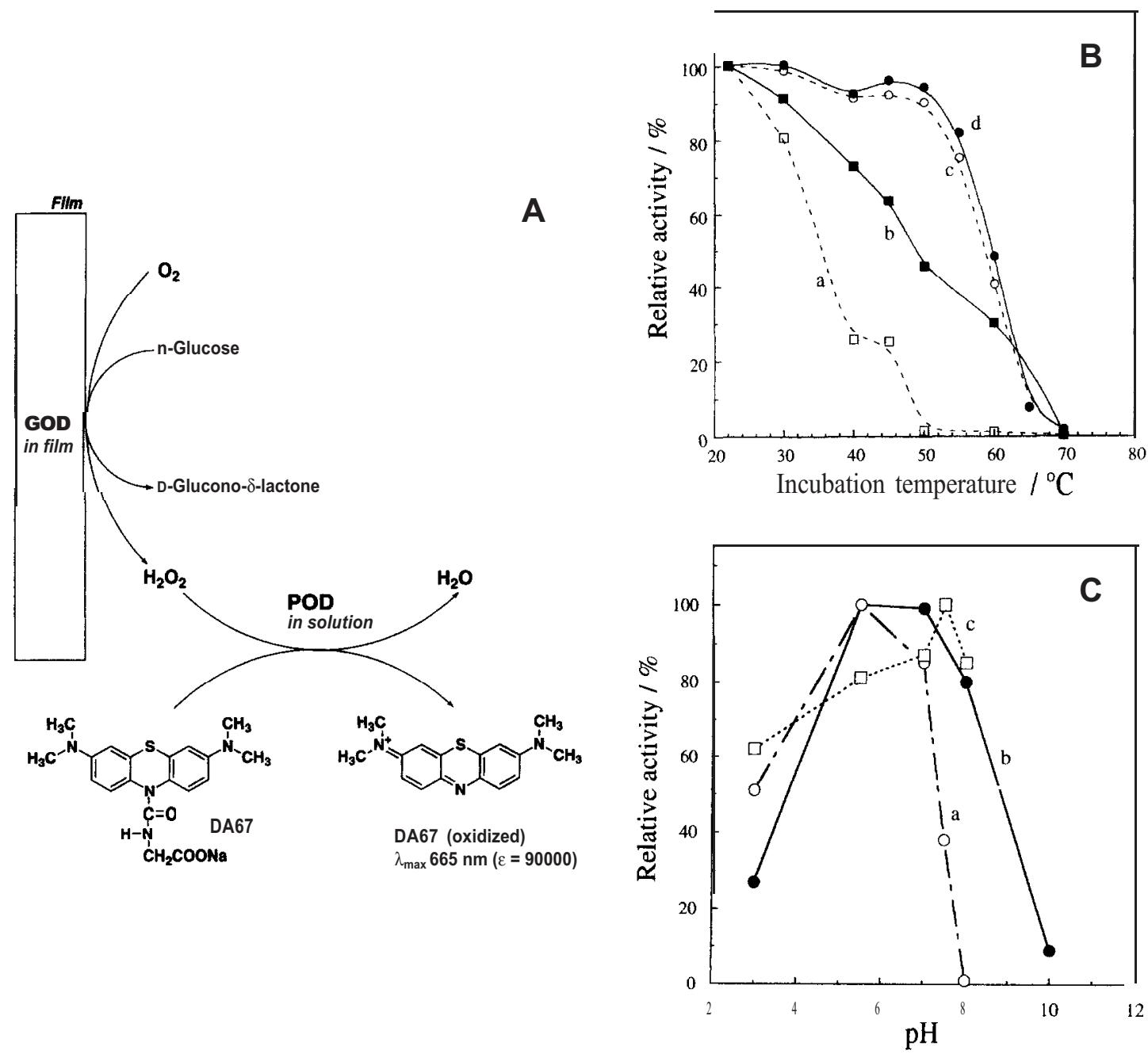

Figure 2. A) Sequential enzymatic process based on film-immobilized GOD and POD, glucose, and DA67 in solution. B) Thermostability of GOD immobilized in aqueous solution $(a, b)$ and in a GOD-PEI film $(c, d)$ : a) relative activity of aqueous GOD immediately after incubation at the given temperatures; b) relative activity of aqueous GOD 30 min after incubation; c) relative activity of GOD in the film immediately after incubation; d) relative activity of GOD in the film 30 min after incubation. C) pH profiles of relative activity of GOD: a) water; b) GOD-PEI film; c) silica gel matrix. Reproduced with permission from [70]. Copyright 1999 Elsevier. 
with nanometer accuracy, LBL assembly will play an important role in the immobilization of biomolecules and the realization of their applications in different fields.

\section{Biomimetics by LBL Techniques}

Mimicking the structures and functions of natural materials has recently been a hot research area because of the superior mechanical, optical, electrical, and biological properties of these materials in comparison with synthetic composites. The LBL technique offers an excellent platform for duplication of natural materials since both share an important featurespontaneous organization.

\subsection{Superstrong Materials}

Many natural materials such as seashells and animal bones possess exceptional mechanical properties, which are believed to originate from the ordered layered structure of inorganicorganic composites (a "brick-and-mortar" structure). ${ }^{[71]}$ Kleinfeld and Ferguson ${ }^{[22]}$ and Kotov et al. ${ }^{[72]}$ duplicated layered seashell structures by LBL assembly of PDDA and anionic clay nanoplatelets. Tang et al. ${ }^{[73]}$ further studied the structure and mechanical properties of freestanding films of PDDA/clay multilayers prepared by the chemical elimination of electrostatic attractions between the multilayers and the glass substrate. ${ }^{[73]}$ Scanning electron microscopy (SEM) imaging (Fig. 3A) revealed the striated architecture of the freestanding film, which is very similar to that of natural seashells. AFM imaging further revealed that the PDDA in the film was adsorbed on the clay nanoplatelets in a tightly coiled conformation (Fig. 3B). The yield stress $(\sigma)$ and Young's modulus $(E)$ of the LBL films were measured to be about $100 \mathrm{MPa}$ and $10 \mathrm{GPa}$, respectively, values close to those of natural seashells (Fig. 3C). More interestingly, for intermediate-stress regions $(10<\sigma<35 \mathrm{MPa})$, all films exhibited a characteristic stepping pattern in the stress-strain curves (Fig. 3C). The inelasticity of the materials can be seen even better in the differential form of the stretching curves (Fig. 3D). As shown by AFM (Fig. 3B), such a pattern was attributed to a successive opening of polymer intrachain loops formed from different polymer segments connected by ionic linkages that were sequentially broken when the macromolecule was extended. These sacrificial bonds were found to be the molecular basis for the mechanical toughness of biocomposites, e.g., bones and seashells, helping to effectively dissipate the energy resulting from stretching deformations. The similar structure and mechanical properties demonstrates that the LBL technique provides a unique nanometer-scale method for the preparation of biomimetic materials with remarkable mechanical properties. More recently, Podsiadlo et al. ${ }^{[74]}$ demonstrated that such nacrelike nanostructured composites exhibited excellent antimicrobial properties after incorporation of Ag NPs into the LBL multilayer.
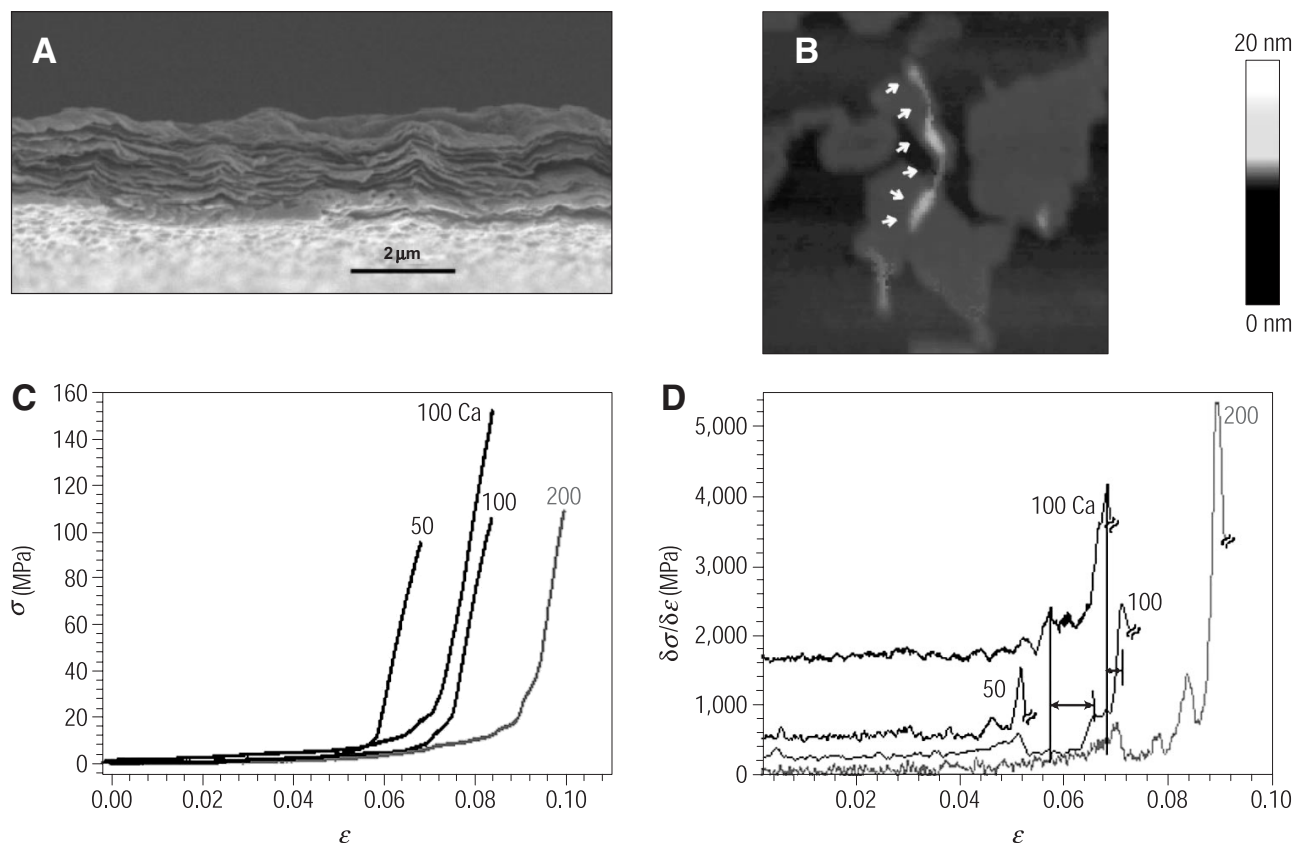

Figure 3. A) SEM image of an edge of a film containing 100 layers of PDDA/clay. B) AFM image $(1 \mu \mathrm{m} \times 1 \mu \mathrm{m})$ of PDDA molecules adsorbed between the clay platelets. C) Mechanical properties of the films. Stress $(\sigma)$ versus strain $(\varepsilon)$ curves of freestanding films made from 50,100 , and 200 layers of $\mathrm{PDDA} /$ clay, and 100 layers of PDDA/clay ion-exchanged with $1 \mathrm{~m} \mathrm{Ca}\left(\mathrm{NO}_{3}\right)$ for $24 \mathrm{~h}$. D) The derivatives of the stretching curves in (C). Reproduced with permission from [73]. Copyright 2003 Nature Publishing Group. 


\subsection{Superhydrophobic Surfaces}

Superhydrophobicity is universally found in Nature, such as in lotus leaves, rice leaves, and the legs of water striders. Since superhydrophobicity is believed to arise from the unique micro- or nanostructures found in Nature ${ }^{[75]}$ the ability to fabricate specific structures using LBL assembly allows one to design functional materials with superhydrophobic surfaces. Soeno et al. ${ }^{[76]}$ were the first to prepare superhydrophobic surfaces by alternative assembly of anionic $\mathrm{SiO}_{2}$ NPs and cationic PAH. After subsequent heating to remove PAH and hydrophobic treatment with dichlorodimethylsilane, they produced a surface with a water contact angle larger than $160^{\circ}$. Zhang et al., ${ }^{[7]}$ Shi et al., ${ }^{[78]}$ and Zhao et al. ${ }^{[79]}$ built on this work by electrodeposition of Ag and Au NPs into the matrix of a LBL film and subsequent spontaneous adsorption of hydrophobic alkanethiols. Sangribsub et al. ${ }^{[80]}$ developed superhydrophobic materials by LBL assembly of cationic PEI or $\mathrm{PAH}$ and anionic polystyrene NPs followed by immersion of the films into a Nafion solution. Jisr et al. ${ }^{[81]}$ showed that, besides NPs, superhydrophobic surfaces can be fabricated by LBL assembly of clay nanorods with perfluorinated polyelectrolytes. Moreover, Zhai et al. ${ }^{[82]}$ mimicked the superhydrophobic behavior of the lotus-leaf structure by creating a honeycomb-like PAH/PAA multilayer surface overcoated with silica NPs. Superhydrophobicity was achieved by coating this highly textured multilayer surface with a semifluorinated silane. All of the above superhydrophobic surfaces prepared by LBL assembly have potential applications as antifogging and self-cleaning materials.

\subsection{Artificial Photosynthesis Membranes}

Photosynthesis is an essential biological process that provides the energy necessary to sustain cellular life, and generation of artificial photosynthesis membranes has always been a dream of scientists. He et al. ${ }^{[83-85]}$ were the first to prepare such photosynthesis membranes by LBL assembly of bacteriorhodopsin (BR) and PDDA. BR is a photochromic protein present in purple membrane, belonging to an important class of light-absorbing proteins that can convert photon energy into a membrane potential. The PDDA/BR LBL films showed a remarkable light-on photocurrent of $52 \mathrm{nA} \mathrm{cm}^{-2}$ for PDDA/ wild-type $\mathrm{BR}$ and $80 \mathrm{nA} \mathrm{cm}^{-2}$ for PDDA/D96N mutant BR. Later studies by Li et al. ${ }^{[86]}$ and Jussila et al. ${ }^{[87]}$ revealed the mechanism of the highly efficient photoconversion in PDDA/ BR LBL films. In addition to BR, other types of biomolecules such as thylakoids, ${ }^{[88]}$ porphyrins, ${ }^{[89,90]}$ and cytochrome $C^{[91]}$ were immobilized to form photosynthesis membranes via electrostatic assembly with oppositely charged partners. It is well known that thylakoids are closed-membrane vesicles inside chloroplasts, the energy-transducing organelles of plant cells, while porphyrin and cytochrome $\mathrm{C}$ are responsible for oxygen transport and storage in living tissues. Thus, light-induced electron-transport processes analogous to those occur- ring in chloroplasts, porphyrin, or cytochrome $\mathrm{C}$ were realized in LBL films that could be used as bio-based solar cells.

\subsection{Biomotors}

Automatic and highly accurate motor protein systems are scientifically intriguing. Replication of this biomechanical behavior would allow us, for example, to develop miniaturized chemical analysis systems. Jaber et al. ${ }^{[2]}$ investigated actomyosin motility on PAH/PSS LBL films with a PAH-terminating surface. Myosin-driven motion of actin filaments was found to have a mean speed of $2.9 \pm 0.08 \mu \mathrm{m} \mathrm{s}^{-1}$ on the multilayer surface, compared with $2.5 \pm 0.06 \mu \mathrm{m} \mathrm{s}^{-1}$ on the monolayer surface. Average filament length increased when a nonionic surfactant was added to myosin, and speed increased with increasing ionic strength of the motility buffer. The remarkable motion of motor proteins shows that LBL films offer a good environment for mimicking biomechanical systems. Furthermore, the speed of motion can be controlled by architectural engineering of the film structure or by an external stimulus.

\subsection{Bioreactors}

Biological systems containing multiple and different types of enzymes are excellent reactors with high efficiency and product selectivity. Finding a good platform with which to load bioactive enzymes is becoming key to the realization of many different reactions. Figure 2 exemplifies a route towards organic synthesis of oxidized DA67 by taking advantage of LBL assembly. Generally speaking, different types of enzymes can be immobilized into films by LBL assembly without loss of bioactivity; these assemblies can then act as highly specific bioreactors. For example, catalyzed oxidation of styrene and $c i s-\beta$-methylstyrene was performed using LBL films of cytochrome $\mathrm{P} 450$ and myoglobin, ${ }^{[93]}$ while dioxygen reduction and hydrogen oxidation were realized by utilizing LBL films of oxidase ${ }^{[94]}$ and hydrogenase ${ }^{[95]}$ respectively.

\section{Biosensors Prepared by LBL Methods}

Preparation of thin-film biosensors is currently one of the most active research areas in the LBL field. ${ }^{[5,52,96,97]}$ Different types of proteins, and even inorganic or organic colloids, can be incorporated into multilayer films and then used as biosensors. In this context, we classify biosensors based on the active sensing components inside the LBL films.

\subsection{Enzyme Biosensors}

Enzyme films as biosensors can be catalogued as two types: oxyreductase biosensors and nonoxyreductase biosensors. 


\subsubsection{Oxyreductase Biosensors}

The principles of operation for using oxyreductase LBL films as biosensors are quite simple. As shown in Figure 4, thin films of oxyreductase enzymes are prepared on electrode surfaces via LBL assembly with oppositely charged species. When

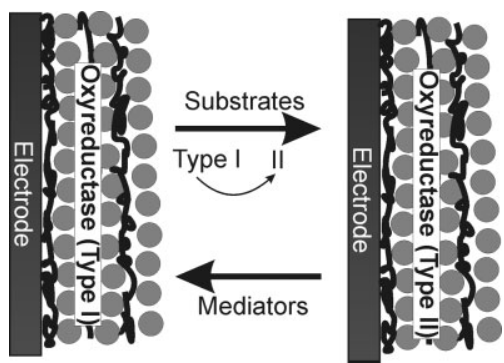

Figure 4. Mechanism of detection for oxyreductase biosensors.

the films are immersed in a solution containing the specific substrates and electric mediators, the oxyreductase will catalyze the conversion of the substrates from type I (reduced or oxidized state) to type II (oxidized or reduced state). At the same time, the oxyreductases themselves are also changed from type I (oxidized or reduced state) to type II (reduced or oxidized state) via the coupling redox reaction. The electronic mediators in solution then react with the oxyreductases of type II and allow the oxyreductases of type II to revert back to type I. By utilizing electrochemical detection of the redox changes of the electronic mediators, we can calculate the concentration of reactants in the solution. Practical preparation and application of LBL films loaded with oxyreductases has proven to be relatively simple and versatile. Almost all types of oxyreductases, including glucose oxidase ${ }^{[98-104]}$ glucose dehydrogenase ${ }^{[105,106]}$ lactate oxidase ${ }^{[107-109]}$ soybean peroxidase,${ }^{[110]}$ pyruvate oxidase,${ }^{[111]}$ horseradish peroxidase, ${ }^{[112-115]}$ fructose dehydrogenase, ${ }^{[116]}$ polyphenol oxidase, ${ }^{[117-119]}$ choline oxidase ${ }^{[120,121]}$ cholesterol oxidase ${ }^{[122,123]}$ uricase ${ }^{[124]}$ xanthine oxidase,${ }^{[125]}$ cytochrome $\mathrm{P} 450$ monooxygenases, ${ }^{[126]}$ manganese peroxidase, and lignin peroxidase ${ }^{[127]}$ have been immobilized to form biosensors. The analytes measured by these sensors also cover a variety of important, biorelated substances: glucose,${ }^{[99]}$ maltose,${ }^{[98]}$ lactate,${ }^{[108]}$ hydrogen peroxide ${ }^{[114]}$ fructose ${ }^{[116]}$ methanol, ${ }^{[116]}$ phenol, ${ }^{[118]}$ choline,${ }^{[121]}$ cholesterol, ${ }^{[122]}$ uric acid, ${ }^{[124]}$ xanthine, ${ }^{[125]}$ poisons, ${ }^{[126]}$ and environmental pollutants. ${ }^{[127]}$ The range of mediators used is relatively small, normally including ferrocene, ${ }^{[99]}$ osmium compounds ${ }^{[102]}$ nicotinamide adenine dinucleotide ${ }^{[106]}$ or $\mathrm{H}_{2} \mathrm{O}_{2} \cdot{ }^{[123]}$ Note that the mediators, like ferrocene ${ }^{[100]}$ and osmium compounds, ${ }^{[101]}$ can be directly grafted onto the polyelectrolyte chains by chemical reaction, and as a result multilayer films with grafted mediators do not need additional mediators in solution; these are known as "wired" enzyme electrodes. ${ }^{[128]}$ The electrochemical detection methods used include measurement of current, potential, or impedance. ${ }^{[5,52,97]}$

\subsubsection{Nonoxyreductase Biosensors}

Films containing nonoxyreductase enzymes such as concanavalin A, organophosphorus hydrolase, urease, and arginase can also be used as biosensors. Because of the absence of redox properties, nonelectrochemical methods are used to characterize the biosensors. Lvov et al. ${ }^{[129]}$ and Sato et al. ${ }^{[130,131]}$ prepared LBL films from anionic concanavalin A and cationic glycogen and subsequently exposed the film to sugar solutions of D-glucose, D-mannose, Me- $a$-D-glucose, and Me- $a$-Dmannose. Free sugars in solution replaced the sugar residues of glycogen at the binding sites of concanavalin A and resulted in the decomposition of the LBL films. The dependence of decomposition rate of the film on the type of sugar and its concentration was evaluated by monitoring the overall mass change of the film using a quartz crystal microbalance (QCM). Constantine et al. ${ }^{[132,133]}$ fabricated organophosphorus hydrolase films by electrostatic assembly with oppositely charged CdSe quantum dots or a highly photoluminescent poly(thiophene-3-acetic acid) polyelectrolyte. The presence of organophosphorus compounds in the solution was detected by measuring a change in the photoluminescence of the film after immersion of the film in the solution. Disawal et al., ${ }^{[134]}$ Nabok et al., ${ }^{[135]}$ and Forrest et al. ${ }^{[136]}$ built up urease and arginase multilayer films by alternating assembly with a cationic polyelectrolyte. By using a $\mathrm{pH}$-sensitive dye, bromocresol purple, as a tracer and recording the optical changes with UV-vis spectroscopy, they were able to study the catalytic activity of the film.

The possible detection methods are multifold. Besides the above electrochemical, gravitational, and optical measurements, the mechanical properties of the film can also be utilized for characterization. ${ }^{[137,138]}$ For example, a GOD multilayer film was prepared on the surface of a microcantilever by Yan et al. ${ }^{[139,140]}$ When exposed to a glucose solution, the functionalized microcantilever underwent selective bending. The formation of the GOD and glucose complex in the films was attributed to the deflection of the cantilever.

\subsection{Immunosensors}

Caruso et al. ${ }^{[141]}$ were the first to prepare an immunosensor by embedding anti-immunoglobulin $\mathrm{G}$ (anti-IgG) monoclonal antibodies into LBL films. QCM and surface plasmon resonance (SPR) confirmed that the films had a specific and sensitive response to $\operatorname{IgG}$ in solution. Brynda et al. ${ }^{[142,143]}$ fabricated multilayer assemblies by the alternating adsorption of monolayers of anti-horseradish peroxidase (anti-HRP) monoclonal antibodies and dextran sulfate at acidic $\mathrm{pH}$. The authors indicated that a sensor employing an LBL multilayer of antibodies exhibited an enhanced sensitivity to the HRP antigens in comparison with those utilizing 2D monolayers, mainly because of the higher number of receptors accessible to the antigens and the better binding properties of antibodies, which were not immobilized directly on the sensor surface. 
The unique advantages of immunosensors prepared by LBL methods including low unspecific background reactivity, high sensitivity, and good response linearity over a large magnitude of antigen concentrations are further disclosed by Diederich et al. ${ }^{[144]}$

\subsection{Protein Sensors}

In this Section, we refer to protein sensors that do not include enzymes, antigens, or antibodies. Analogous to the oxyreductases described in Section 4.1, the redox proteins responsible for oxygen transport and storage in living tissues, e.g., cytochrome, ${ }^{[145-148]}$ myoglobin, ${ }^{[145,149]}$ and hemoglobin, ${ }^{[150,151]}$ were immobilized on the surface as electrochemical sensors to detect oxygen and superoxide in solution. As other examples, Anzai et al. ${ }^{[152,153]}$ and Inoue et al. ${ }^{[154]}$ took advantage of specific biorecognition between biotin and avidin and prepared biosensors. By immobilizing either biotin or avidin in the LBL films, QCM measurements showed that the prepared film had an excellent response to its complementary partner.

\subsection{Nucleic Acids and DNA Sensors}

The specific and strong interactions of double-stranded DNA (dsDNA) has also been utilized to prepare biosensors. QCM measurements have shown that single-stranded DNA (ssDNA) contained in LBL films exhibit extremely high sensitivity and selectivity towards their complementary ssDNA in solution. ${ }^{[155,156]}$ This biosensor could lead to a rapid, low-cost, and convenient diagnostic method for detection and recognition of genetic diseases. Besides direct monitoring of complementary DNA strands, Rusling and co-workers extended the application of DNA sensors to the detection of chemical toxicity. ${ }^{[146,157-159]}$ Their method was based on two facts: guanine is the most easily oxidized of the four DNA bases, and ssDNA is more easily oxidized at the guanine or adenine sites than dsDNA because of easier access to the bases. When LBL films of dsDNA were exposed to a solution of toxic chemicals, the dsDNA in the film was damaged and the double helix was unwound. Easier access to the nucleobases was enabled, leading to faster reaction rates and larger electrochemical detection signals.

\subsection{Biosensors from Inorganic Colloids and Organic Molecules}

Immobilization of inorganic colloids or organic molecules in LBL films can be utilized in the preparation of sensors for the detection of substances that may have a significant impact on biological processes. Liu et al. ${ }^{[160,161]}$ fabricated films of heteropolyanion clusters and used them as $\mathrm{pH}$ - or NO-sensitive probes. Yu et al. ${ }^{[162]}$ and Qian et al. ${ }^{[163]}$ incorporated $\mathrm{Au}$
NPs into films that exhibited a fast response to NO and ascorbic acid. Ram et al. ${ }^{[164]}$ detected $\mathrm{CO}$ by using LBL films of $\mathrm{SnO}_{2}$ or $\mathrm{TiO}_{2}$ NPs. Koktysh et al. ${ }^{[165]}$ and Zhang et al. ${ }^{[166]}$ embedded $\mathrm{TiO}_{2}$ nanoshells and multiwalled carbon nanotubes, respectively, into LBL films and studied their dopamine-sensing properties. Cheng et al. ${ }^{[167]}$ prepared ruthenium metallodendrimer multilayer films and used them as sensors for insulin. Fiorito et al. ${ }^{[168]}$ explored the application of Prussian blue NP LBL films as $\mathrm{H}_{2} \mathrm{O}_{2}$ sensors.

\subsection{Selectivity of Biosensors}

Selectivity is always one of the most important parameters in determining the efficiency of biosensors. Since LBL assembly enables assembly on the molecular level, their application as biosensors can certainly benefit from smart structural design of the films. Koktysh et al. ${ }^{[165]}$ were the first to utilize the nanometer-scale properties of inorganic materials for LBLfabricated biosensors. They fabricated a LBL film of PAA and $\mathrm{TiO}_{2}$ nanoshells, which had an external diameter of 10$30 \mathrm{~nm}$ and a wall thickness of 3-5 nm and were synthesized by dissolving the silver cores of $\mathrm{Ag} @ \mathrm{TiO}_{2}$ NPs in a concentrated solution of ammonium hydroxide (Fig. 5A-C). As shown in Figure 5B and C, there were some pores in the $\mathrm{TiO}_{2}$ shells, the diameters of which are comparable to the thickness of the electrical double layer in porous matter $(0.3-30 \mathrm{~nm})$. As a result, formation of a network of voids and channels in the interior of the $\mathrm{TiO}_{2}$-shell film produced strong ion-sieving properties because of the exclusion of some ions from the diffusion region of the electrical double layer. The authors confirmed the ion-separation effect of the $\mathrm{TiO}_{2}$-shell film by selective characterization of one of the most important neurotransmitters, dopamine, on a background of ascorbic acid (Fig. 5D-F). Under physiological conditions, the negative charge on the surface of $\mathrm{TiO}_{2}$ facilitated permeation of positively charged dopamine through the LBL film to the electrode, thus preventing access of the negatively charged ascorbic acid. The deposition of the nanoshell/polyelectrolyte film resulted in a significant improvement of the selectivity for dopamine. As such, creative design of LBL structures has allowed for the preparation of films that could be used as implantable biomedical devices for nerve-tissue monitoring. Hoshi et al. ${ }^{[169]}$ successfully used $\mathrm{Pt}$ electrodes coated with polyallylamine/poly(vinyl sulfate) or poly(allylamine)/PSS films to detect $\mathrm{H}_{2} \mathrm{O}_{2}$ in the presence of potentially interfering agents. It was suggested that $\mathrm{H}_{2} \mathrm{O}_{2}$ diffused into the multilayer film smoothly while the ascorbic acid, uric acid, and acetaminophen could not penetrate the film because of a size-exclusion mechanism. On the other hand, the electrodes coated with films containing cationic PEI or PDDA were not useful for the selective detection of $\mathrm{H}_{2} \mathrm{O}_{2}$. Malaisamy et al. ${ }^{[170]}$ prepared 4.5 bilayers of PSS/PDDA on polyethersulfone ultrafiltration supports and showed that the selectivity of the film is 100:1 for a glucose:raffinose system. Rmaile et al. ${ }^{[171]}$ and Kamande et al. ${ }^{[172]}$ developed ultrathin films of chiral L- and 

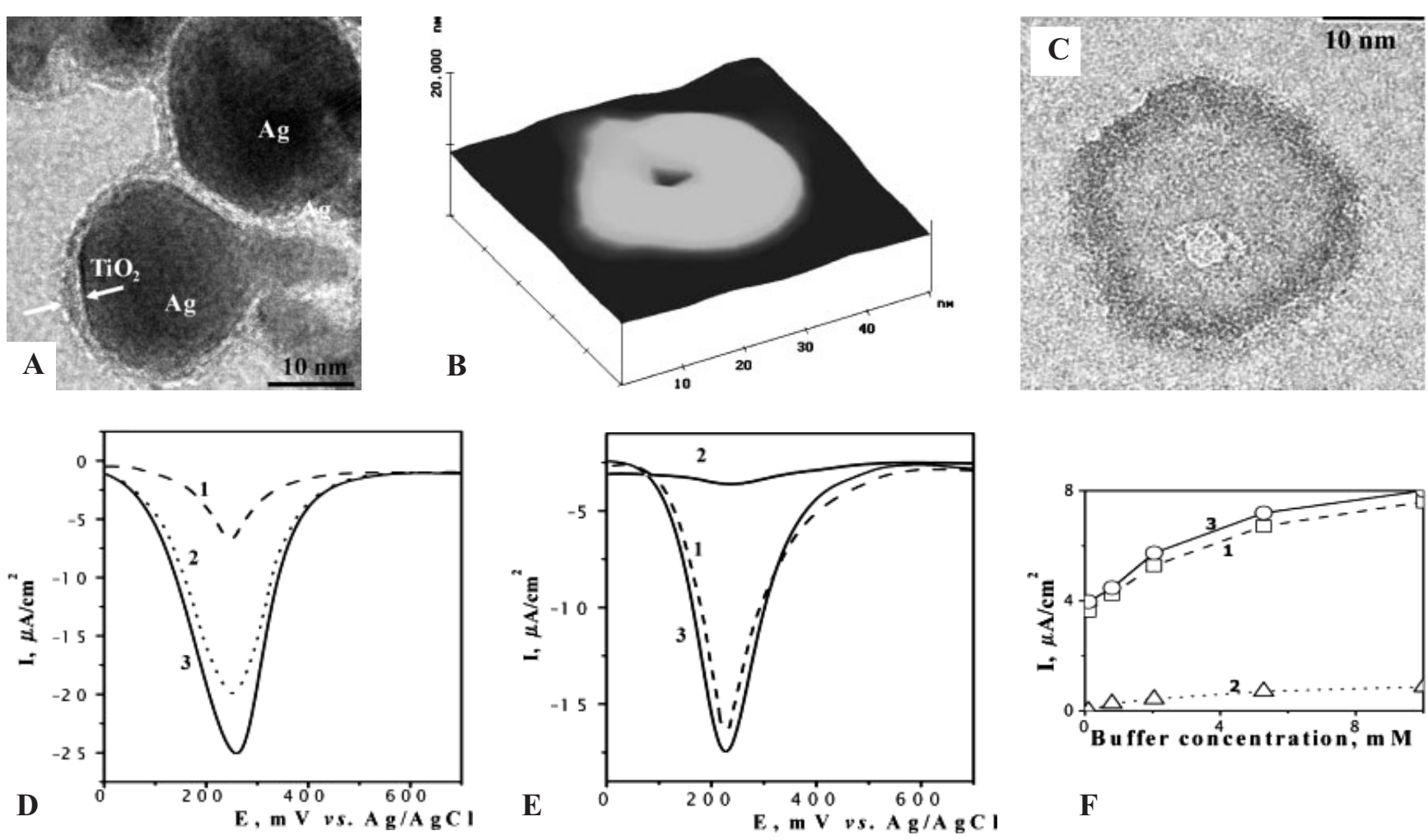

Figure 5. A) Transmission electron microscopy (TEM) image of $\mathrm{Ag} / \mathrm{TiO}_{2}$ core/shell NPs. B) AFM and C) TEM images of TiO ${ }_{2}$ shell NPs. D,E) Differential pulse voltammograms (DPVs) for 1) $1 \mathrm{~mm}$ dopamine; 2) $1 \mathrm{~mm}$ ascorbic acid; and 3) a mixture of $1 \mathrm{~mm}$ dopamine and $1 \mathrm{~mm}$ ascorbic acid in $0.1 \mathrm{~m}$ phosphate buffer for a nascent electrode (D) and an electrode coated with PDDA(PAA/TiO $)_{20}(\mathrm{E})$. F) A plot of the peak currents of the DPVs. Reproduced from [165].

D-poly(lysine), poly(glutamic acid), and poly $(N-(S)$-2-methylbutyl-4-vinyl pyridinium iodide), and applied the films as chiral separators for different types of organic compounds.

\section{Applications of LBL Assembly in Drug Delivery}

A major challenge in the development of advanced drug formulations is the elaboration of delivery systems capable of providing sustained release of bioactive materials. Sustainedand controlled-release mechanisms offer greater effectiveness, lower toxicity, and improved patient convenience over conventional formulations. ${ }^{[173,174]}$ In the context of controlled release, the LBL fabrication procedure offers potential advantages over conventional protein and nucleic acid encapsulation strategies, including 1) the ability to control the order and location of multiple polymer layers with nanometer-scale precision and 2) the ability to define the concentrations of incorporated materials simply by varying the number of polymer layers. ${ }^{[46]}$

The release behavior would be dependent on the permeability or breakdown of the multilayer structure. In this Section, we review this research according to the different stimuli pathways utilized for triggering the "deconstruction", or dissolution, of multilayered assemblies.

\section{1. pH-Stimulated Release}

Chung et al. ${ }^{[175]}$ studied loading capability and release behavior of multilayer films of PAH and PAA using the dye methylene blue as an indicator. PAA/PAH multilayers assembled at $\mathrm{pH} 2.5 / 2.5$ had the capability to load methylene blue inside the multilayers because of the available binding sites - carboxylate groups on PAA - and its permeable structure. Release studies demonstrated a $\mathrm{pH}$-sensitive unloading mechanism, where lower-pH environments increased the release rate. This resulted from the disruption of the electrostatic bonds between methylene blue and the carboxylate groups of PAA as carboxylate groups were converted to carboxylic acid groups. In addition, a diffusion barrier was built up by assembling capping layers of $\mathrm{PAA} / \mathrm{PAH}$ at $\mathrm{pH} 6.5 / 6.5$ on top of the 2.5/2.5 PAA/PAH multilayers. These fully ionized polymer chains formed a highly ionically crosslinked system, which prevented the multilayer from expanding and swelling and, in turn, hindered methylene blue diffusion. Other studies of $\mathrm{pH}$-dependent loading and release behavior in polyelectrolyte multilayer films have drawn similar conclusions: incorporation and release of materials from such films depends on the degree of film swelling, the ability of the probe molecules to aggregate in the film, and the attractive and repulsive interactions occurring between the probe molecules and the acidic/basic functional groups in the film. ${ }^{[176]}$ 
$\mathrm{pH}$-stimulated reversible switching of dye or protein uptake and release in LBL-assembled multilayered films has also been achieved. ${ }^{[177,178]}$ For example, Mueller et al. ${ }^{[17]}$ constructed LBL thin films consisting of PEI and PAA. It was demonstrated that adsorption of a positively charged protein took place at $\mathrm{pH} 7.3$, where the outermost layer of the film was negatively charged. Complete desorption was obtained at pH4, where the external layer was neutral. An alternative means of realizing controlled release stimulated by $\mathrm{pH}$ changes is to fabricate thin films using components that exhibit $\mathrm{pH}$-dependent degradation. Based on this concept, Wood et al. ${ }^{[179]}$ produced LBL thin films by alternate deposition of a degradable poly( $\beta$-amino ester) and polysaccharides, which show $\mathrm{pH}$-induced degradation and release behavior. The highly versatile and tunable properties of these materials make them suitable candidates for the controlled release of a wide spectrum of therapeutics.

\subsection{Ionic-Strength-Stimulated Release}

Similar to the delamination mechanism of multilayer thin films using $\mathrm{pH}$ as the stimulus, changing the ionic strength of a solution has also been utilized to control the electrostatic interactions between polyelectrolytes or macromolecules and proteins, leading to improvements in stability or degradation of thin films depending on the chemical compositions within the composites. ${ }^{[180,181]}$ Dubas et al. ${ }^{[180]}$ have shown that PAA/ PDDA multilayered films were rapidly removed at salt concentrations greater than $0.6 \mathrm{~m}$ because the polyelectrolytes within multilayers were dissociated by ion-exchange competition of salt ions for polymer/polymer ion pairs. Sukhishvili et al. ${ }^{[182]}$ demonstrated that in highly concentrated salt solutions the instability and erasability of multilayer thin films fabricated using hydrogen-bonding polymer complexes decreased. The reason is that the ions reduce the intensity of electrostatic repulsion between a given number of ionized groups within a multilayer assembly.

\subsection{Electrically Stimulated Release}

Studies of strategies for introducing a programmed decrease of polymer-polymer interactions, and thus controlled degradation of polymer thin films, have suggested that the charge status of the macromolecules within the films is one of the key factors for decomposition of LBL multilayers. Analogous to the effect of changing environmental $\mathrm{pH}$ and ionic strength, an external electric field is known to shift the equilibrium between neutral and charged states of polyelectrolytes, ${ }^{[183]}$ which suggests the potential usefulness of this strategy for controlling the stability of multilayers. ${ }^{[182]}$ In addition, an electric field facilitates the build-up of LBL multilayer films. Yamauchi et al. ${ }^{[184]}$ demonstrated LBL deposition of PEI and plasmid DNA on indium tin oxide (ITO) electrodes for specific gene transfer. The sequential assembly process was highly effective in stable loading of plasmids onto the ITO surface under physiological conditions. The loaded plasmids were subsequently released from the electrode upon application of an electric pulse and transferred into cells cultured on the electrode.

\subsection{Thermo-Stimulated Release}

As an alternative to the examples discussed above, novel thermoresponsive thin-film systems have been produced using the LBL method that show thermal tunability in uptake and release. Among all the studied systems, hydrogels have been the most extensively studied as a vehicle for controlled drug release. ${ }^{[185,186]}$ Poly( $N$-isopropylacrylamide) (PNIPAm) is one of the most widely studied thermoresponsive hydrogels. These gels undergo a reversible volume phase transition at a lower critical solution temperature of $31^{\circ} \mathrm{C}$, where the hydrogel hydrophobically collapses upon itself, expelling water in an entropically favored fashion. ${ }^{[187]}$ This reversible shrinking event has been used as a means of controlling the uptake and release of various model drugs. Quinn et al. ${ }^{[188,189]}$ demonstrated that multilayers containing PNIPAm could be reversibly loaded with dye tracers and emptied by varying the temperature of the surrounding solution. Inspection of the kinetics of adsorption and release of the multilayer PAA/PNIPAm films revealed a strong dependence on both the solution temperature and film preparation temperature, as shown in Figure 6A and $\mathrm{B}$, leading to tunable loading/release properties. Nolan et al. ${ }^{[190]}$ also investigated thermally triggered insulin release from LBL multilayer films, which were constructed by alternating assembly of microgel particles with PAH.

\subsection{Photo-Stimulated Release}

It is worth mentioning that hydrolysis of a polyelectrolyte can also be stimulated by light. Such photohydrolysis techniques have been employed to tune the permeability of multilayered polyelectrolyte membranes. Jensen et al. ${ }^{[191]}$ built up photohydrolyzable films of $\mathrm{PAH}$ and PAA that was first partially esterified with various benzyl groups (e.g. benzyl, 3-methoxybenzyl, 3,5-dimethoxybenzyl, 2-nitrobenzyl). Upon exposure to UV light, the benzyl groups photohydrolyzed, the permeability of the resulting films increased dramatically, and a certain degree of ion selectivity was achieved.

\subsection{Hydrolytically Induced Release}

The integration of design elements that enable the dissolution, disintegration, or erosion of multilayered polyelectrolyte assemblies under physiological conditions would facilitate application of these structured materials in therapeutic contexts, ${ }^{[192]}$ where changes in ionic strength or $\mathrm{pH}$ are restricted or undesirable. Towards this goal, there are a few reports on 

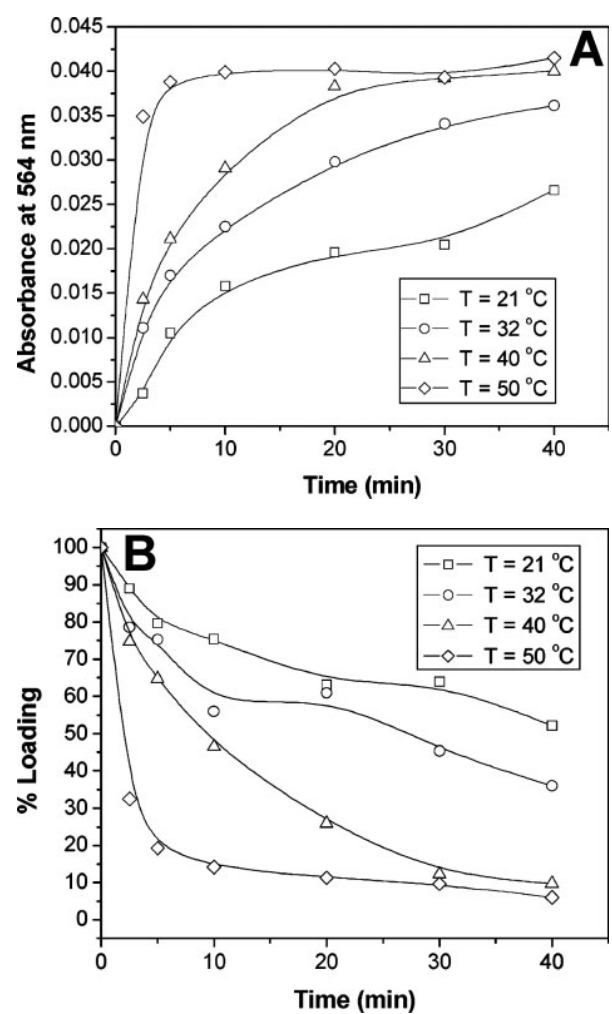

Figure 6. A) Impregnation profiles at different temperatures for multilayer thin films exposed to $0.01 \mathrm{mg} \mathrm{mL}^{-1}$ Rhodamine B, pH 3.0. B) Release profiles at different temperatures for multilayer thin films impregnated with Rhodamine $B$ upon exposure to dilute $\mathrm{HCl}(\mathrm{pH} 3.0)$. Reproduced with permission from [188]. Copyright 2004 American Chemical Society.

preparation of multilayer assemblies incorporating hydrolytically degradable macromolecules that erode gradually when incubated under physiological conditions. ${ }^{[193]}$ Zhang et al. ${ }^{[194]}$ fabricated multilayered assemblies consisting of alternating layers of plasmid DNA and a synthetic degradable polyamine. These assemblies eroded gradually upon incubation in phosphate-buffered saline at $37^{\circ} \mathrm{C}$ and sustained the release of incorporated plasmid for a period of up to $30 \mathrm{~h}$. They further demonstrated that the plasmid was released in a transcriptionally active form that promoted significant levels of gene expression in mammalian-cell-transfection experiments. Based on the same concept, the so-called "prodrug approach", i.e., when a drug is linked to a biocompatible polymer via a hydrolyzable bond, has emerged as a powerful method for controlling the release of a variety of therapeutics to a targeted site. Thierry et al. ${ }^{[195]}$ designed a platform for delivery of hydrophobic drugs such as paclitaxel, one of the most potent chemotherapeutic agents in the treatment of breast and ovarian cancers, via a prodrug approach combined with the LBL technique. They used a hyaluronan (HA) ester prodrug of paclitaxel as the polyanion to construct polyelectrolyte multilayers with chitosan $(\mathrm{CH})$, a polyamine. Release of the drug from the paclitaxel-loaded multilayers upon hydrolysis of the ester linkage resulted in rapid cell death.

\subsection{Enzymatically Induced Release}

As mentioned before, the scope of materials that can be incorporated into multilayered polyelectrolyte assemblies is broad and includes enzymes. Degradation of multilayer films can be achieved via suitable combinations of biopolymers and enzymes, which hydrolyze the corresponding biopolymers in the LBL assembly. Serizawa et al. ${ }^{[196]}$ first reported desorption of the LBL assembly between cationic $\mathrm{CH}$ and anionic dextran sulfate through the hydrolysis of $\mathrm{CH}$ by chitosanase. Later, the same group demonstrated time-controlled desorption of polymer films triggered by enzymatic degradation. ${ }^{[197]}$ In this case, they developed a LBL assembly consisting of an anionic biopolymer (DNA), a cationic synthetic polymer (PDDA), and an endonuclease (DNase I) as a single-component-specific enzyme (Fig. 7A). Time-controlled desorption was accomplished based on the fact that the activity of DNase I was strongly dependent on the concentration of essential metal ions, $\mathrm{Mg}^{2+}$ and $\mathrm{Ca}^{2+}$, which accelerated hydrolysis of the DNA (Fig. 7B).
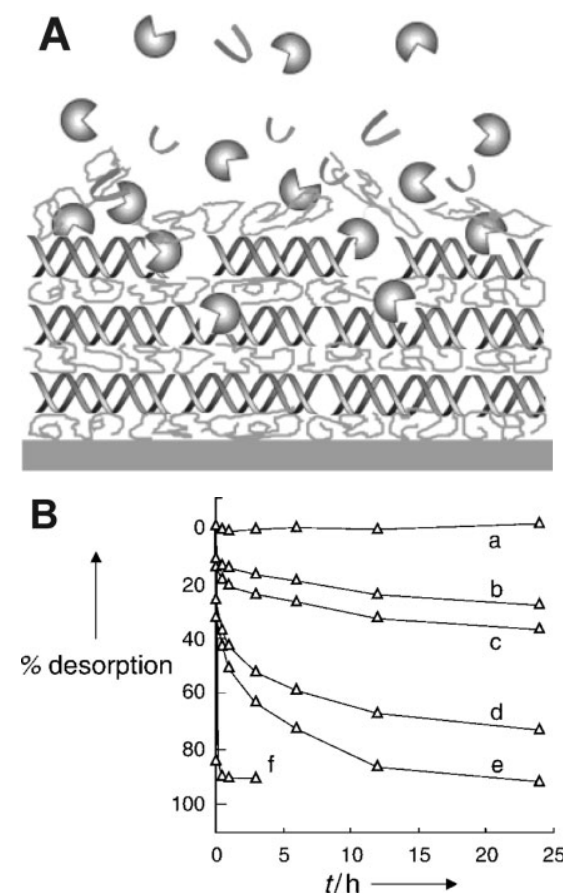

Figure 7. A) Schematic representation of the enzymatic hydrolysis of a DNA/PDDA assembly. B) Desorption (\%) of the LBL assembly with an outer surface composed of PDDA triggered by the enzymatic degradation of DNA in the assembly at $258^{\circ} \mathrm{C}$ and at $\mathrm{Mg}^{2+}$ and $\mathrm{Ca}^{2+}$ concentrations of a) 0 , b) 0.5 , c) 1 , d) 3 , e) 5 , and f) $50 \mathrm{~mm}$ after electrostatic condensation of the enzyme at $48^{\circ} \mathrm{C}$. Reproduced from [197].

\subsection{Self-Degradable Multilayers}

All the systems we have discussed so far use external stimuli to trigger deconstruction of the multilayered thin films. An alternative approach to realize film degradation without trigger- 
ing events but rather by introduction of self-biodegradable products into the LBL process is also possible. ${ }^{[198,199]}$ This not only contributes to the list of unique biomedical functionalities of LBL biomaterials but also to chemical recycling. One example is provided by Serizawa et al., ${ }^{[198]}$ who prepared multilayered thin films made of biodegradable and also naturally produced $\mathrm{CH}$ and poly $(\gamma$-glutamic acid) (PGGA).

\section{Adhesion of Proteins and Cells on LBL Films}

Controlling adhesion of proteins and cells on surfaces is one of the critical steps towards preparation of biomedical devices. The simplicity of coating with LBL films on geometrically complex substrates provides a rational method towards realization of this target at a molecular level.

\subsection{Protein Adsorption and Diffusion inside LBL Films}

Adsorption of proteins onto LBL films is a complex phenomenon attributed to electrostatic forces, hydrogen bonds, hydrophobic interactions, and hydrophilic repulsion. ${ }^{[200-202]}$ Ladam et al., ${ }^{[203,204]}$ Gergely et al., ${ }^{[201]}$ Muller et al., ${ }^{[205]}$ and Salloum et al. ${ }^{[200]}$ studied the charge effect of LBL surfaces on the adsorption behavior of different types of proteins, including serum albumin, fibrinogen, and lysozyme. They found that proteins strongly interacted with the LBL films regardless of the sign of the charges for both the multilayers and the proteins. When the charges of the multilayers and the proteins were similar, one monolayer of proteins was observed to adhere on the film because of the hydrogen-bonding and hydrophobic interactions. When the protein and the multilayer were oppositely charged, the electrostatic interactions became dominant. Therefore, the adsorbed amount of protein dramatically increased and the formation of thick protein layers, extending up to several times the largest dimension of the protein, was observed. Schwinte et al. ${ }^{[206]}$ further investigated the effect of surface charges on the secondary structure of the adsorbed protein and found that the structural changes were larger when the charges of the multilayer outer layers and the proteins were opposite. Salloum et al. ${ }^{[200]}$ took advantage of hydrophilic repulsion to minimize the protein adsorption through fabrication of LBL films of a diblock copolymer comprising a hydrophilic poly(ethylene oxide) block.

Szyk et al. ${ }^{[207,208]}$ investigated the diffusion behavior of human serum albumin adsorbed on, or embedded inside, a PSS/ PAH multilayer film. Although the diffusion coefficients of proteins varied as a function of the surface concentration of adsorbed proteins and the types of terminating polyelectrolytes, the proteins were found to exhibit large lateral mobilities regardless of their position on the surface and inside the LBL films, which constituted a key result for the practical application of LBL films as targeted biomaterial coatings. ${ }^{\text {[207] }}$

\subsection{Cell Attachment to LBL Films}

Modification of the surface properties of substrates by LBL coating can effectively control the attachment behavior of cells. Boura et al. ${ }^{[209]}$ reported that the adhesion of human umbilical vein endothelial cells (HUVEC) was enhanced after modification of the substrate's surface with multilayer films of PSS/PAH or PLGA/poly(D-lysine) (PDL). In comparison with modification of PDL or PAH monolayers, the multilayer remarkably increased the initial cell attachment (Table 1). More importantly, the biological responses of HUVEC cells seeded onto the LBL films were not altered by the evaluation in terms of initial attachment, growth, cellular metabolic activity, endothelial phenotype, or adhesion (Table 1). Cell growth on the LBL films was found to be similar to that on tissue culture polystyrene. Gheith et al. ${ }^{[210]}$ showed that single-walled carbon nanotube polyelectrolyte multilayers and freestanding films could serve as biocompatible platforms for seeding and differentiation of neuronal cells and might be used in neuroprosthetic implantable devices. LBL techniques were also used to cover hydrophobic or cell-resistant substrates in order to promote cell attachment. Y. Zhu et al. ${ }^{[211]}$ and H. Zhu et al. ${ }^{[212]}$ prepared LBL films on polyester and poly(D,L-lactide) scaffolds and observed enhancement of the cell attachment and differentiation. Ai et al. ${ }^{[213]}$ also coated LBL multilayers on silicone rubber in order to improve cell adhesion and growth. One of the most prominent features of the LBL technique is the capability of modifying substrates with any geometry (in contrast to conventional 2D coating techniques like spin-coating). Glawe et al. ${ }^{[214]}$ coated microchannel scaf-

Table 1. Initial attachment, growth, and adhesion after trypsin treatment of HUVEC cells seeded on polyelectrolyte multilayers and control surfaces. TCPS: tissue-culture polystyrene. Reproduced with permission from [209]. Copyright 2003 Elsevier.

\begin{tabular}{|c|c|c|c|c|}
\hline Surfaces & $\begin{array}{c}\text { Initial cell attachment } \\
{[\%]}\end{array}$ & $\begin{array}{l}\text { Number of cells at } 24 \mathrm{~h} \\
\left.\qquad \times 10^{4} \text { cells cm } \mathrm{cm}^{-2}\right]\end{array}$ & $\begin{array}{l}\text { Number of cells at } 72 \mathrm{~h} \\
{\left[\times 10^{4} \text { cells cm } \mathrm{cm}^{-2}\right]}\end{array}$ & $\begin{array}{l}\text { Adherent cells after trypsin treatment } \\
\qquad[\%]\end{array}$ \\
\hline PEI-(PSS-PAH) $)_{2}-\mathrm{PGA}-\mathrm{PDL}$ & $77.5 \pm 10.0$ & $1.65 \pm 0.54$ & $4.08 \pm 0.68[b]$ & $33.8 \pm 9.3$ [a] \\
\hline PEI-(PSS-PAH) $)_{2}$-PSS-PAH & $106.8 \pm 19.3$ & $1.72 \pm 0.62$ & $4.93 \pm 0.96[b]$ & $83.1 \pm 13.3[\mathrm{a}, \mathrm{b}]$ \\
\hline PDL & $51.8 \pm 13.8[a, b]$ & $0.79 \pm 0.14[a, b]$ & $2.89 \pm 0.62[a, b]$ & $88.6 \pm 6.2[a, b]$ \\
\hline $\mathrm{PAH}$ & $55.5 \pm 15.7[a, b]$ & $0.75 \pm 0.20[a, b]$ & $2.02 \pm 0.43[a, b]$ & $83.8 \pm 10.3[a, b]$ \\
\hline Glass & $95.5 \pm 4.0$ & $1.75 \pm 0.14$ & $6.67 \pm 0.36[\mathrm{a}]$ & $32.5 \pm 4.0[\mathrm{a}]$ \\
\hline TCPS & 100 & $1.40 \pm 0.18$ & $4.73 \pm 1.03[b]$ & $63.9 \pm 13.2$ \\
\hline
\end{tabular}

[a] $p<0.05$ versus TCPS. [b] $p<0.05$ versus glass. 
folds for the promotion of smooth muscle cell adhesion by LBL multilayers and controlled the cell alignment inside the channels. Zhu et al., ${ }^{[215]}$ Liu et al., ${ }^{[216]}$ and Lee et al. ${ }^{[217]}$ demonstrated that LBL multilayers could be coated on the surface of 3D scaffolds for the promotion of cell seeding and growth.

LBL coating can also be used to alter the cytotoxicity of substrates, as demonstrated by Sinani et al. ${ }^{[218]}$ LBL films of semiconductor NPs have unique optical, magnetic, and electrical properties, and can be interfaced with different types of cells for the fabrication of artificial biomedical devices. ${ }^{[49]}$ However, semiconductor NP materials based on heavy metals are cytotoxic, as evidenced by the fact that rare $\mathrm{C} 2 \mathrm{Cl} 2$ myoblast cells could not be grown on films of PDDA/CdTe NPs (Fig. 8A). When the CdTe NPs films were coated with a single PAA/collagen bilayer, the behavior of cells changed dramatically (Fig. 8B). They attached in large quantities and spread over the surface, indicating that the cytotoxicity of $\mathrm{Cd}$ and $\mathrm{Te}$ was markedly screened. They also showed signs of aggregation into large colonies. When the number of collagen bilayers was increased to (PAA/collagen $)_{5}$, the total number of cells that attached also increased-they covered the entire surface of the film in a confluent monolayer (Fig. 8C). PC12 cells reacted differently: the cells tended to clump and remained loosely attached (Fig. 8D), in comparison with PC12 cells grown on glass (Fig. 8E) treated with the standard attachment factor polyornithine. Cytotoxicity was determined by assaying the activity of lactate dehydrogenase in the media. The cytotoxicity of CdTe NPs films coated with (PAA/collagen) $)_{5}$ was measured to be the same as the control polystyrene dish, which indicated excellent screening of $\mathrm{Cd}$ and Te cytotoxicity by LBL films.

It should be noted that there are many factors affecting the adhesion and growth behaviors of cells on LBL films under cell-culture conditions. Analogous to the adsorption of proteins, cells with negative charges prefer to seed on LBL films
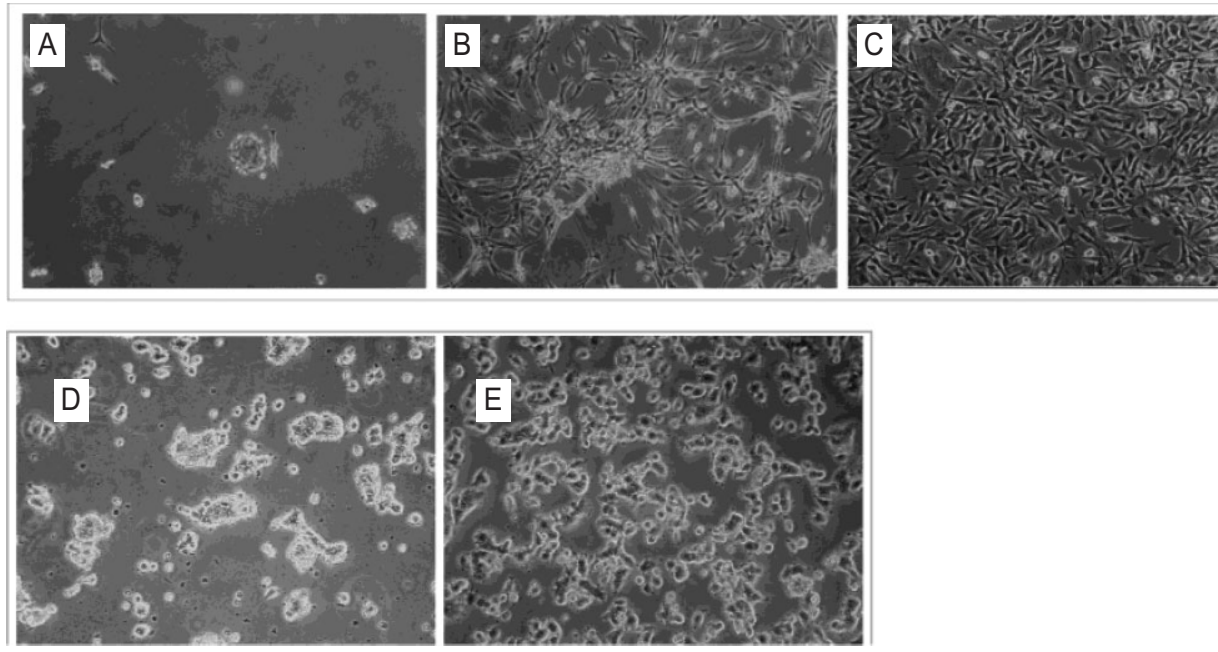

Figure 8. Optical microscopy images of a-c) $\mathrm{C} 2 \mathrm{Cl} 2$ myoblast and d,e) $\mathrm{PC} 12$ culture cells on the surface of

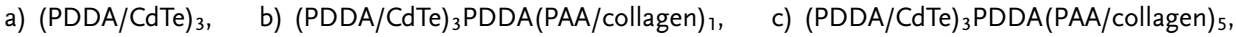
d) $(\mathrm{PDDA} / \mathrm{CdTe})_{3} \mathrm{PDDA}(\mathrm{PAA} / \mathrm{collagen})_{5}$, and e) glass. Reproduced with permission from [218]. Copyright 2003 American Chemical Society. terminated with positively charged polyelectrolytes. ${ }^{[27,219]}$ When cell culture was performed in serum-containing media, competitive adsorption against proteins in the serum led to a decrease in cell adhesion on the LBL films. ${ }^{[27,220]}$ The intrinsic structures of LBL films also have large effects on the cell attachment. Kreke et al. ${ }^{[221]}$ and Jessel et al. ${ }^{[22]}$ demonstrated that incorporation of heparin and protein A in LBL films improved the adhesion of mouse-calvaria-derived osteoprogenitor cells and monocytic THP-1 cells, respectively, whereas Hahn et al. ${ }^{[223]}$ and Hwang et al. ${ }^{[224]}$ showed that embedding hyaluronic acid in the LBL film prevented seeding of peripheral blood mononuclear cells. Engler et al. ${ }^{[225]}$ tested adhesion of smooth muscle cells on PLL/hyaluronic acid LBL films and found that adhesive spreading of cells correlated closely with the effective stiffness of the films. Mendelsohn et al., ${ }^{[26]}$ Yang et al., ${ }^{[22]}$ and Richert et al. ${ }^{[28]}$ reported the design of cytophilic and cytophobic surfaces by controlling the intrinsic structures of LBL films. It is known that, in contrast to PDDA and PSS, the ionization and surface charges of PAH, PAA, PLL, and PLGA are strongly dependent on the $\mathrm{pH}$ of the solution because they are weak polyelectrolytes. ${ }^{[229]}$ For instance, the negative charges of PAA decrease with the solution $\mathrm{pH}$, and thus PAA adopts a more coiled structure in a LBL film because of the decrease of charge repulsion in the polyelectrolyte chain. On the other hand, cationic $\mathrm{PAH}$ adopts a morecoiled structure in a high-pH solution. As shown in Figure 9C, the surface of a PAH/PAA multilayer film prepared from pH6.5 solutions (denoted as 6.5/6.5 PAH/PAA) was thin and smooth because the large number of net charges in both chains of PAA and PAH allowed them to be immobilized in the film in the stretched conformation. When PAH and PAA were deposited at $\mathrm{pH} 7.5$ and at $\mathrm{pH} 3.5$, respectively (7.5/ 3.5 PAH/PAA), both the partially ionized PAA and PAH molecules adsorbed in loop-rich conformations, forming thick layers with a high degree of internal charge pairing and many interior water molecules (Fig. 9A). ${ }^{[226]}$ The abundant charges of the 6.5/6.5 PAH/PAA film provided a good niche for murine NR6WT fibroblast cells to seed and grow, whereas the strong hydrophilic repulsion of 7.5/3.5 PAH/PAA films prevented cell adhesion (Fig. 9D,E).

Some groups ${ }^{[230-232]}$ are endeavoring to position cell growth on the substrates by LBL techniques. The general idea is to deposit cytophilic or cytophobic LBL films for the improvement or prevention of cell adhesion at desired positions on the substrates by ink-jet printing, photolithography, or polymer-on-polymer stamping. ${ }^{[233]}$ 

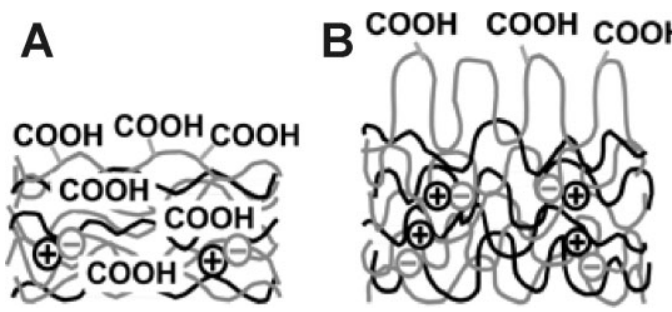

C
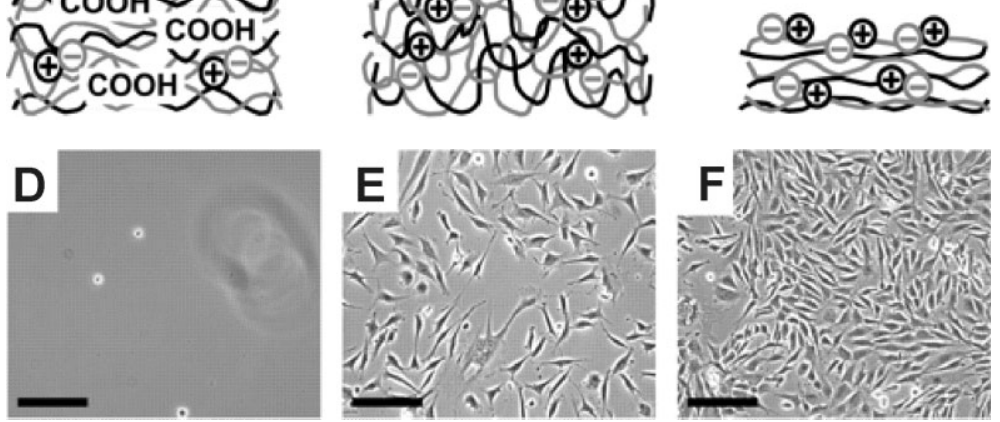

Figure 9. Schematics of A) 2.0/2.0, B) 7.5/3.5, and C) 6.5/6.5 PAH/PAA multilayer assemblies shown with PAA as the outermost layer. D-F) Phase-contrast microscopy images acquired on day 3 of murine NR6WT fibroblasts seeded at 10000 cells cm onto D) a 2.0/2.0 (20 layer) PAH/PAA multilayer, E) a 7.5/3.5 (20 layer) PAH/PAA multilayer, and F) a 6.5/6.5 (50 layer) PAH/PAA multilayer. Scale bars are $200 \mu \mathrm{m}$. Reproduced with permission from [226]. Copyright 2003 American Chemical Society.

\subsection{Bone Cells}

LBL multilayer films can potentially also be used as new biocompatible coatings for bone implants. Tryoen-Toth et al. ${ }^{[238]}$ systematically investigated the viability, adhesion, and bone phenotype of SaOS-2 osteoblast-like cells and human periodontal ligament cells on different polyelectrolyte multilayer architectures: PEI-(PSS/PAH), PEI-(PSS/PAH $)_{2}$-PGA, PEI-(PSS/PAH $)_{2}-(\mathrm{PGA} /$ $\mathrm{PLL})_{2}, \mathrm{PEI}-(\mathrm{PSS} / \mathrm{PAH})_{2}$-PSS, and PEI-(PSS/PEI) (Fig. 10). Higher cell adhesion was observed on PAH-, PGA-, and PLL-terminating films for both cell types than for control plastic or glass surfaces, while the number of attached cells was intermediate and low for both cell types on PSS and PEI surfaces, respectively (Fig. 10A and B). The phenotype expression in SaOS-2 and periodontal ligament cells grown on different polyelectrolyte multilayer films was explored using two osteoblast phenotypic markers, alkaline phosphatase as an early marker and osteocalcin as a later osteoblast expression marker. Significant downregulation of

\section{Mediation of Cellular Functions by LBL Films}

The ease of controlling the structure of LBL films possibly allows us to manipulate adhesion, differentiation, proliferation, and even function of the attached cells at the molecular level, which will eventually allow for their application in tissue engineering. ${ }^{\text {[234] }}$

\subsection{Endothelial Cells}

Endothelial cells make up the inside of blood vessels. The adhesion of endothelial cells onto functional biomaterials can improve the nonthrombogenic properties of these surfaces. Boura et al. ${ }^{[235,236]}$ evaluated the adhesion properties of endothelial cells onto two types of LBL films capped either by PDL or PAH, and compared them to data obtained for PDL or PAH monolayers, glass, and fibronectin-coated glass. The results showed higher cell viability on the LBL multilayers, inducing higher cell numbers compared with polyelectrolyte monolayers after 1 and 3 days of culture. Moreover, the cells showed a normal cytoskeleton morphology. The phenotype of the endothelial cells was maintained and a low level of leukocyte adhesion molecules was observed. Zhu et al. ${ }^{[237]}$ reported that the polymer scaffolds after LBL coating exhibited excellent biocompatibility for seeding and proliferation of endothelial cells. All of the above studies demonstrate the possible application of LBL techniques in vascular-tissue engineering. alkaline phosphatase mRNA was measured in both cell types after $24 \mathrm{~h}$ of contact with PEI-terminating constructs, while slight downregulation was observed for SaOS-2 cells seeded on PAH or PGA surfaces and for periodontal ligament cells seeded on PAH or PLL surfaces, respectively (Fig. 10C and D). Osteocalcin mRNA expression in SaOS-2 cells at $24 \mathrm{~h}$ did not seem to be influenced by any of the polyelectrolyte films tested, while in PDL cells clearly detectable downregulation of the osteocalcin message was found when the cells were grown on PAH- or PEI-terminating films (Fig. 10E and F). Interleukin-8 (IL-8) secretion in SaOS-2 and PDL cells after $24 \mathrm{~h}$ of contact was used to evaluate the behavior of the polyelectrolyte multilayer constructions toward pro-inflammatory processes. As shown in Figure 10G, in the culture supernatant of SaOS-2 for cells grown on PAH- or PEIterminating films, the IL- 8 level was increased by 45 or $35 \%$, respectively, and no effect was detected with PGA-, PLL-, or PSS-terminating layers. The stimulating effect of PAH and PEI surfaces on IL-8 production was even more drastic. On PAH- and PEI-terminating films, periodontal ligament cells secreted 3.5 and 5.5 times more IL-8, respectively, than the cells grown on plastic (Fig. 10H). Summarizing this investigation, one can draw the conclusion that PSS- and PGA-ending films have good biocompatibility towards periodontal ligament cells, and PSS-, PGA-, and PLL-terminating films are good candidates for SaOS-2 cell growth. The LBL films have also been used to coat the surface of polymer scaffolds, exhibiting excellent biocompatibility for bone-cell attachment and growth. ${ }^{[239,240]}$ 

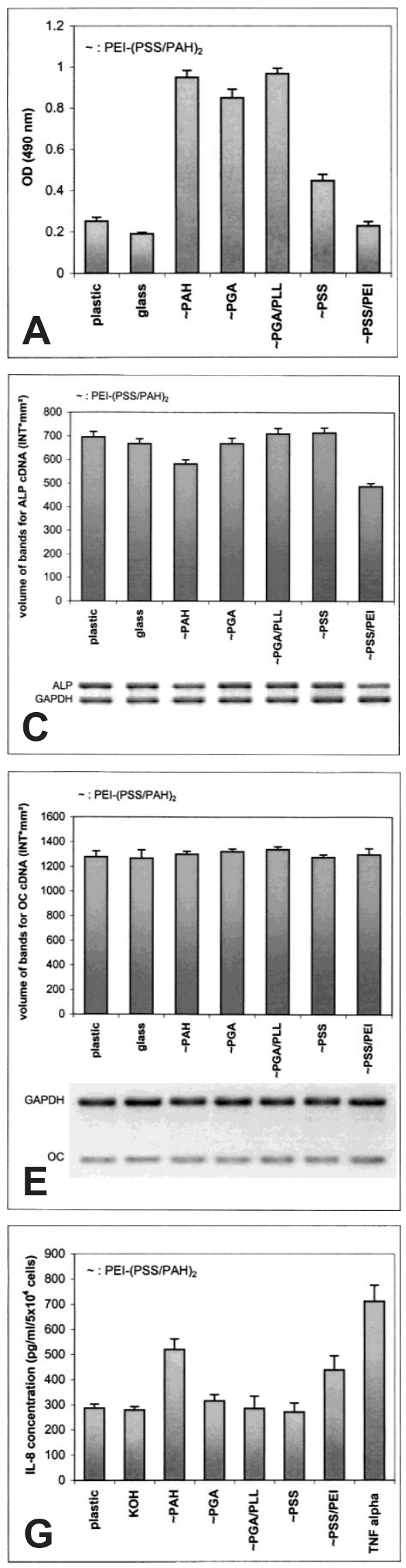
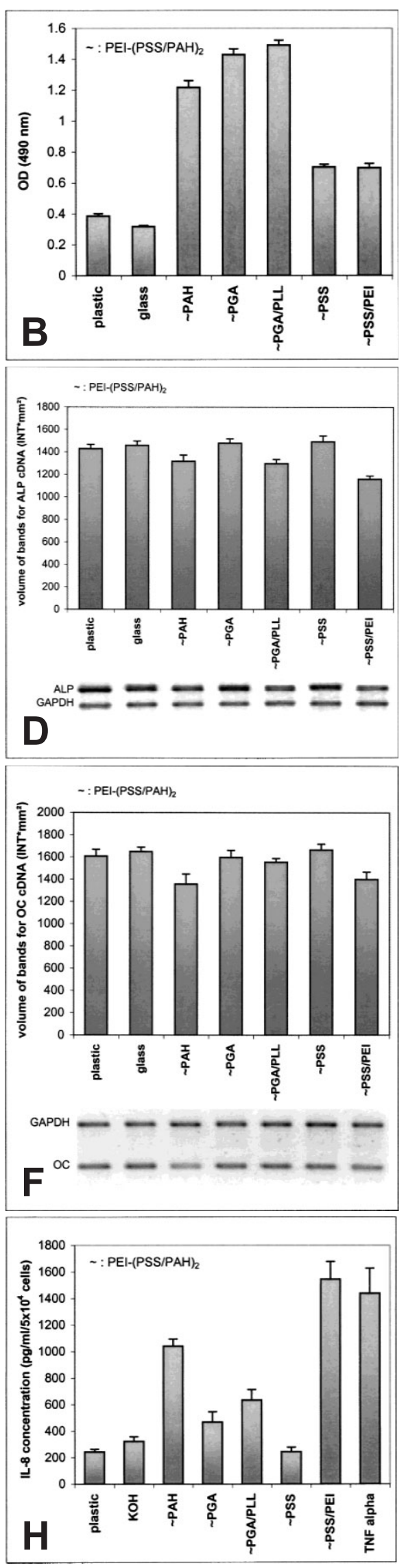

Figure 10. $A, B$ ) Adhesion of SaOS-2 osteoblast-like cells $(A)$ and human periodontal ligament cells (B) on various coated surfaces $20 \mathrm{~min}$ after seeding. OD: optical density. C,D) Effect of different polyelectrolyte multilayer constructions on the expression of alkaline phosphatase (ALP) specific mRNA in SaOS-2 cells (C) and periodontal ligament cells (D), and $E, F$ ) osteocalcin (OC) RNA in SaOS-2 cells (E) and periodontal ligament cells ( $F$ ) grown on different polyelectrolyte films after $24 \mathrm{~h}$ of contact with the substratum. GAPDH: glyceraldehyde-3-phosphate dehydrogenase. $\mathrm{G}, \mathrm{H}$ ) Effect of polyelectrolyte multilayer films on interleukin-8 (IL-8) production by SaOS-2 cells $(G)$ and human periodontal ligament cells (H). TNF-alpha: tumor necrosis factor alpha. Reproduced from [238]. 


\subsection{Tumor Cells}

Melanoma cells are a cancerous form of melanocytes, the cells that produce skin color or pigment (melanin). Melanoma cells respond specifically to a small peptide hormone, $\alpha$-melanocortin, which is a potent stimulator of melanogenesis. Chluba et al. ${ }^{[21]}$ showed remarkable conservation of full biological activity of $a$-melanocortin both for covalently bonded peptides to the surface of LBL films and when peptides were embedded in a LBL multilayer. In comparison with conventional coating methods, polyelectrolyte multilayers are easily prepared and retain their bioactivity after storage in the dry state, allowing for broad medical applications as implantable devices or artificial tissues. Vautier et al. ${ }^{[242]}$ investigated the growth behavior of chondrosarcoma cells on polyelectrolyte multilayers with various terminating layers in the presence of serum. Chondrosarcoma is a malignant tumor that produces cartilage matrix. Induction of IL-8 secretion was detected on PAH- and PLL-terminating polyelectrolyte films. Early cellular adherence was enhanced with PGA-, PAH-, PLL-, and, to a lesser extent, with PSS-terminating layers. The presence of actin filaments and vinculin focal adhesions was observed on PSS- or PAH-terminating films, while such phenomena were partially or totally absent on PGA- and PLL-terminating multilayer architectures. For PLL-terminating films, vinculin and actin organization was clearly dependent on the number of deposited layers. The results of this study suggest that PSS-terminating multilayered films constitute a controlling interfacial microenvironment at the material surface for chondrosarcoma cells.

\subsection{Fibroblast Cells}

Fibroblasts are the cells that make up the structural fibers and foundation of connective tissues. Mao et al. ${ }^{[243]}$ made use of acidic fibroblast growth factor (aFGF) in the presence of heparin (as a negatively charged polyelectrolyte) and fabricated multilayer films by alternate assembly with cationic PEI. The fibroblasts proliferated faster on the surface assembled with five bilayers of (aFGF/heparin)/PEI, with apparent higher cytoviability than on those surfaces modified by one bilayer of (aFGF/heparin)/PEI, five bilayers of $\mathrm{aFGF} /$ PEI, or five bilayers of heparin/PEI, or just tissue-culture polystyrene. Enhanced secretion of collagen type I and interleukin- 6 by the fibroblasts seeded on the five bilayers of (aFGF/heparin)/PEI was also verified by immunohistochemical examination.

\subsection{Tissue Engineering}

One of the final targets of LBL coating is their application in tissue engineering. ${ }^{[234]}$ Elbert et al. ${ }^{[24]}$ prepared thin polymer films on model tissue surfaces, like the fibroblast extra- cellular matrix, using the LBL technique in order to evaluate the feasibility of using such a technique to build barrier materials on the surfaces of tissues to improve post-surgical healing, or on the surfaces of tissue-engineered implants. Their results indicated that the thin polymer layers were relatively bioinert and that the thicknesses of the assemblies correlated with the degree of bioinertness, such that interactions of cells with the underlying proteinaceous surface could be prevented. Khademhosseini et al. ${ }^{[245,246]}$ and Fukuda et al. ${ }^{[247]}$ took advantage of patterned LBL films for the study of cellular co-cultures. It is well known that co-cultures of two or more cell types may better mimic in vivo systems and explore cell-cell interactions, which is important for the development of tissue-engineering constructs and in vitro cultures that mimic the organization and complexity of normal tissue architecture. $^{[246]}$ As shown in Figure 11A, non-biofouling HA micropatterns can prevent the adsorption of fibronectin proteins and subsequent seeding of a cell type A. In the next step, ionic adsorption of poly(L-lysine) onto HA patterns was used to switch the HA surfaces from cell-repulsive to cell-adherent, thereby facilitating the adhesion of a second cell type B. To adopt this strategy, Khademhosseini et al. ${ }^{[246]}$ successfully fabricated patterned co-cultures of embryonic stem cells with NIH-3T3 fibroblasts (Fig. 11B) or AML12 hepatocyte cells with NIH-3T3 fibroblasts (Fig. 11C). The fact that such co-cultures remained stable for at least five days further confirmed that the patterned LBL technique can potentially provide a valuable tool for studying cell-cell interactions, maintaining cells in culture, and engineering organs for tissue engineering.

Very recently, Lee et al. ${ }^{[217]}$ developed an alternative LBL method to realize co-culture of cells. LBL assembly of clay/ PDDA multilayers was used to modify the surface of 3D scaffolds and to enhance the adhesion of thymic epithelial cells. Simultaneously, the spherical chambers of 3D scaffolds were used to entrap the floating monocyte cells, which spent most of the time in close proximity to the matrix and bone epithelial cells adhering to the walls of the $3 \mathrm{D}$ scaffold. Using this approach, they efficiently simulated the differentiation niches for different components of the hematopietic system, including T-cells, B-cells, and stem cells.

\section{Implantable Materials Prepared by LBL}

Armed with the knowledge introduced above, scientists have fabricated implantable devices using the LBL technique for possible in vivo diagnosis and therapy.

\subsection{Anti-Biofouling Properties}

One of the basic requirements of implantable devices is good anti-biofouling properties, which encompass antiadhesion, anti-inflammatory, and antibacterial properties. 
A

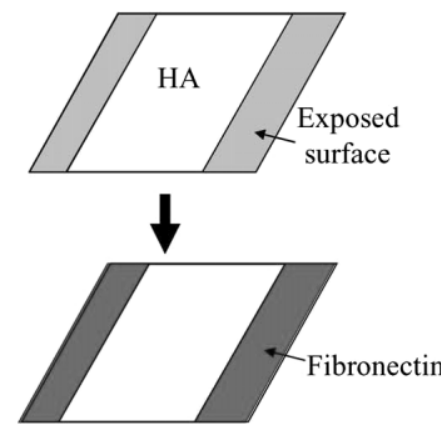

$$
\begin{gathered}
\text { Seed cell } \\
\text { type A }
\end{gathered}
$$
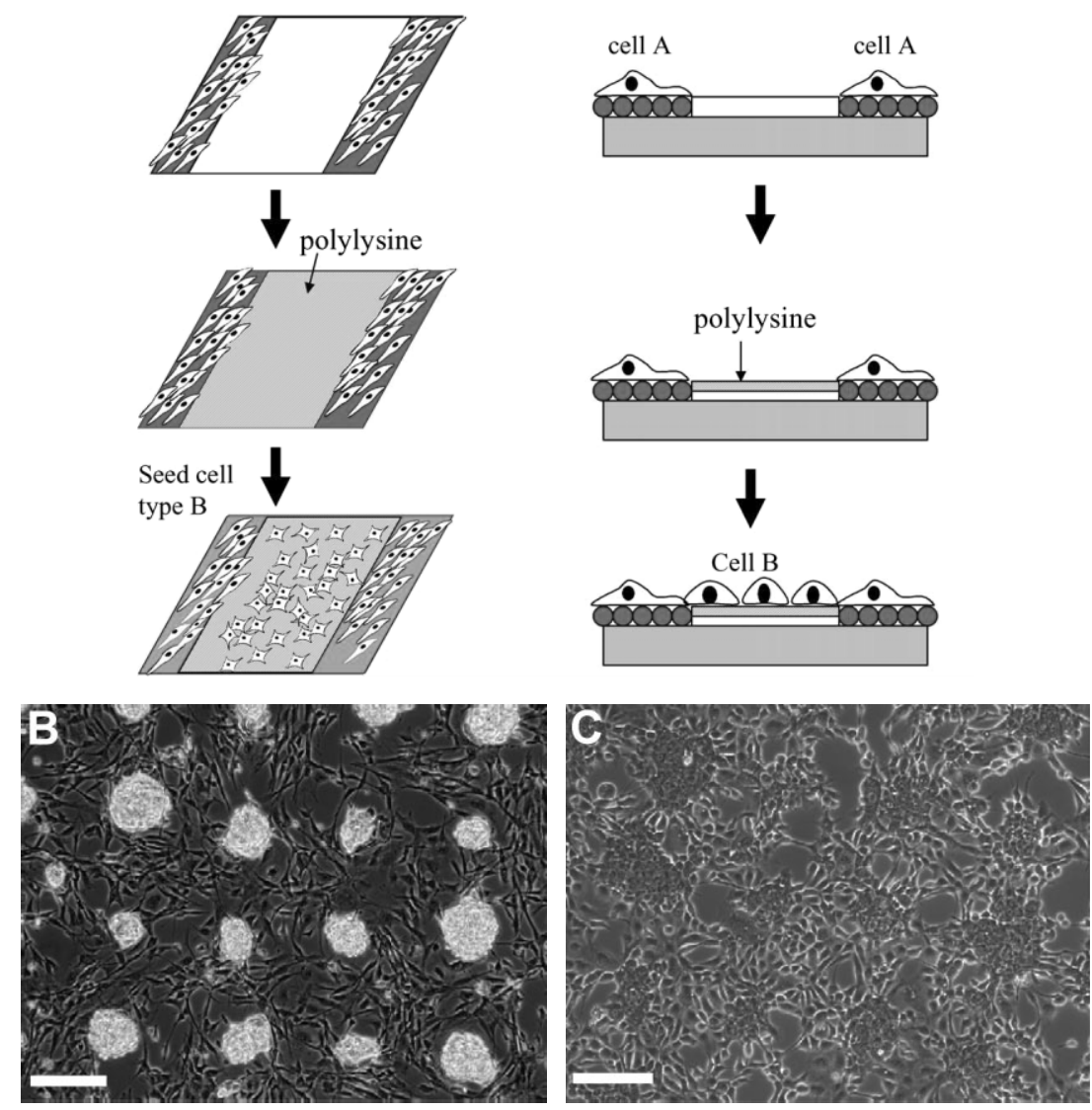

Figure 11. A) Schematic diagram of the HA-PLL layering approach to pattern co-cultures. Patterned co-cultures of B) embryonic stem cells with NIH-3T3 fibroblasts and C) AML12 hepatocyte cells with NIH-3T3 fibroblasts. Scale bars represent $200 \mu \mathrm{m}$. Reproduced with permission from [246]. Copyright 2004 Elsevier.

\subsubsection{Antiadhesion Properties}

Implantable devices should have the capability to prevent platelet adhesion and then blood coagulation. Many research groups confirmed that coating with LBL films containing serum albumin,${ }^{[38,248-251]}$ heparin, ${ }^{[38,248,250,252,253]}$ dextran, ${ }^{[196,254]}$ and $\mathrm{CH}^{[196,252,254,255]}$ can efficiently enhance resistance to blood coagulation. As an example, Thierry et al. ${ }^{[256]}$ constructed a multilayer film of $\mathrm{HA}$ and $\mathrm{CH}$ on the surface of a stent in the presence of a nitric oxide donor, sodium nitroprusside. Stents have been extensively used in cardiovascular surgery where they are inserted into clogged arteries, previously opened using a procedure such as balloon angioplasty or atherectomy, to prevent localized constriction of the artery. Enhanced thromboresistance of the LBL multilayer together with the anti-inflammatory and wound-healing properties of $\mathrm{HA}$ and $\mathrm{CH}$ are expected to reduce the neointimal hyperplasia, or thickening of the interior layer of the blood vessel, associated with the stent implantation. Moreover, LBL films of collagen and immunosuppressive agents, such as sirolimus, on the surface of stents could serve as reservoirs for sustained drug release. ${ }^{[257]}$

\subsubsection{Anti-Inflammatory Properties}

Benkirane-Jessel et al. ${ }^{[258,259]}$ incorporated a melanocortin derivative and piroxicam into multilayer films on a model implant surface and evaluated its antiinflammatory properties by detecting the inhibition of TNF-alpha produced by human monocyte cells stimulated with lipopolysaccharide bacterial endotoxin. Such a surface coating upon LBL modification exhibited a remarkable anti-inflammatory response; thus, this coating may be applied to implants or prostheses.

\subsubsection{Antibacterial Properties}

Bacterial infection of implanted materials is one of the most severe concerns following prosthetic surgery. Because of the abundance of hydrogen bonds and strong hydrophilic repulsion, polysaccharide multilayers of HA and $\mathrm{CH}$ can be used not only to prevent adhesion of cells, as introduced in Section 8.1.2, but also as an antibacterial coating. ${ }^{[260]}$ In order to take advantage of the hydrophilic repulsion, Boulmedais et al. ${ }^{[261]}$ constructed multilayer films of PLL and PLGA with surface-grafted poly(ethylene glycol), and prepared films with good bacterial resistance. Etienne et al. ${ }^{[262,263]}$ further showed that the antibacterial capability of LBL coatings was dramatically enhanced by the insertion of an antimicrobial peptide (e.g., defensin, chromofungin) into the multilayers. Another antibacterial agent, silver, has been recognized for over a century. ${ }^{[264]}$ Grunlan et al, ${ }^{[265]}$ Podsiadlo et al., ${ }^{[74]}$ and Lee et al. ${ }^{[266]}$ incorporated silver NPs into LBL multilayers and achieved films with good antibacterial properties. Overall, 
the tremendous improvement of antibacterial capability, which can be realized by LBL coatings with multiple antibacterial agents, will ensure the safety of implanted materials.

\subsection{Biosensors}

In vivo diagnosis requires biosensors with small sizes. Chen et al. ${ }^{[267]}$ coated the tips of gold wires having diameters of $250 \mu \mathrm{m}$ with GOD using the LBL technique. The biosensors allowed for $>2 \mathrm{nA} \mathrm{mM}^{-1}$ sensitivity, 0-30 mu dynamic range, drift of about $5 \%$ per $24 \mathrm{~h}$ at $37^{\circ} \mathrm{C}$ at a glucose concentration of $15 \mathrm{~mm}$, and about a $5 \%$ current increment using a combination with $0.1 \mathrm{~mm}$ ascorbate, $0.2 \mathrm{~mm}$ acetaminophen, and $0.5 \mathrm{~mm}$ urate. Sensors with LBL micromembranes accurately measured glycemia in the jugular vein and in the interstitial subcutaneous fluids. Multilayer films containing humic acids were prepared on the surfaces of biosensors as a potential semipermeable membrane. ${ }^{[268]}$ The permeability of glucose through these membranes was shown to be regulated by varying the number of assembled layers. Moreover, a $200 \mathrm{~nm}$ thick LBL film had a shear modulus of about $80 \mathrm{MPa}$, implying stability upon implantation. These films were also found to be biocompatible, since in vivo studies indicated only mild tissue reactions along with some neovascularization.

Silicon microelectrode arrays have great potential for enabling chronic in vivo recording of neural activity; however, this promise is hampered by scar-tissue formation at the site of implantation. ${ }^{[26]} \mathrm{He}$ et al. ${ }^{[269]}$ reported that a LBL multilayer coating on the silicon microelectrode arrays significantly enhances cortical neuronal attachment and differentiation in vitro with no deleterious effects on impedance of the electrodes. Therefore, LBL techniques could benefit development of biosensors for in vivo monitoring.

\subsection{Repair of Vessels}

Thrombogenesis easily occurs at the position where an artery is damaged, resulting in one of the leading causes of death today. ${ }^{[192]}$ Thierry et al. ${ }^{[270]}$ coated the interior of damaged arteries with a polysaccharide multilayer of $\mathrm{HA}$ and $\mathrm{CH}$. An $87 \%$ reduction in platelet adhesion was observed for the damaged artery coated by the polysaccharide film (Fig. 12).

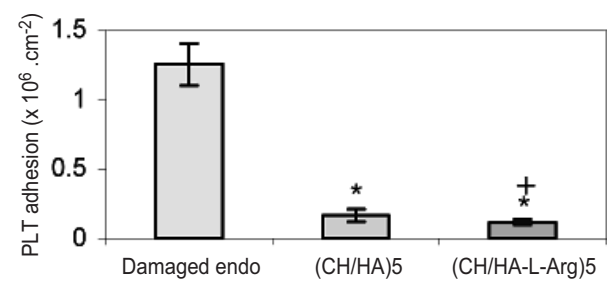

Figure 12. Platelet (PLT) adhesion on damaged endothelium ("damaged endo"), $(\mathrm{CH} / \mathrm{HA})_{5}$-coated damaged endothelium, and ( $\left.\mathrm{CH} / \mathrm{HA}-\mathrm{L}-\mathrm{Arg}\right)_{5}$ coated damaged endothelium. Reproduced with permission from [270]. Copyright 2003 American Chemical Society.
The cause of the reduction in platelet adhesion for the polysaccharide multilayer has been discussed in Section 8.1. A nitric oxide precursor, L-arginine, was used as a drug model and incorporated within the multilayer films. Nitric oxide is known to affect vascular tone and wall dynamics, to inhibit monocyte and platelet adhesion, and to prevent vascular-cell proliferation. As shown in Figure 12, arginine-loaded polysaccharide multilayers further reduced platelet adhesion by $91 \%$, demonstrating the potential of LBL technique in artery repair.

\section{Concluding Remarks}

As a molecular-assembly technique, LBL assembly has been extensively used in biology, spanning biomimetics to tissue engineering. However, the biological applications of the LBL method are still in the early stages, and many treasures still await scientific discovery. From a theoretical viewpoint, the effects of LBL films on seeding and growth behavior of cells remain elusive. All parameters of LBL films, including the surface charges, surface hydrophobicity or hydrophilicity, surface roughness, intrinsic structures, and mechanical strength, can influence the biological behavior of cells. More importantly, as described in Section 7, different types of cells exhibit different attachment and differentiation, even on LBL films with the same structure. General theoretical models that offer a full understanding of the LBL effect on the behavior of the attached cells are urgently required.

There are also numerous opportunities regarding the practical biomedical applications of LBL techniques. For instance, the LBL method is known to have the capability to incorporate almost all types of high-molecular-weight hydrophilic species with a variety of functionalities. This property makes LBL deposition a central technique for the incorporation of the achievements of nanotechnology in biomaterials and biomedical devices. Thus, organic-inorganic LBL films with unique optical, electric, magnetic, and thermal properties originating from NPs, nanowires, carbon nanotubes, clay platelets, and other nanocolloids can be fabricated and subsequently interfaced with attached proteins and cells. Such complexes of nanostructured and biological entities with specific, finely tuned functions have no analogues in conventional materials, offering promise for a broad range of applications in diagnosis and treatment.

The LBL method is also a unique technique for preparing coatings not only on 2D flat substrates, but also on 3D scaffolds. It can be expected that LBL-assembled films with specific embedded growth factors, receptors, or ligands deposited on complex 3D scaffolds will push the development of tissue engineering. In summary, we truly believe that the LBL method has a very bright future in biological applications and can become a pivotal and enabling technique for the development of a variety of biomedical procedures and devices.

Received: January 17, 2006

Published online: November 16, 2006 
[1] Langmuir-Blodgett Films (Ed: G. Roberts), Kluwer Academic, Norwell, MA 1990.

[2] D. H. McCullough, III, S. L. Regen, Chem. Commun. 2004, 2787.

[3] M. Mrksich, G. M. Whitesides, Annu. Rev. Biophys. Biomol. Struct. 1996, 25,55 .

[4] M. Mrksich, Chem. Soc. Rev. 2000, 29, 267.

[5] Protein Architecture: Interfacing Molecular Assemblies and Immobilization Biotechnology (Eds: Y. Lvov, H. Moehwald), Marcel Dekker, New York 2000.

[6] I. Langmuir, V. J. Schaefer, J. Am. Chem. Soc. 1937, 59, 2075.

[7] K. B. Blodgett, J. Am. Chem. Soc. 1935, 57, 1007.

[8] R. G. Nuzzo, D. L. Allara, J. Am. Chem. Soc. 1983, 105, 4481.

[9] C. D. Bain, G. M. Whitesides, J. Am. Chem. Soc. 1989, 111, 7164.

[10] V. Erokhin, in Handbook of Thin Film Materials, Vol. 1 (Ed: H. S. Nalwa), Academic, San Diego, CA 2002, Ch. 10.

[11] V. Erokhin, in Protein Architecture: Interfacing Molecular Assemblies and Immobilization Biotechnology (Eds: Y. Lvov, H. Moehwald), Marcel Dekker, New York 2000, Ch. 5.

[12] W. Senaratne, L. Andruzzi, C. K. Ober, Biomacromolecules 2005, 6 , 2427.

[13] G. Decher, J. D. Hong, J. Schmitt, Thin Solid Films 1992, 210, 831.

[14] G. Decher, Science 1997, 277, 1232.

[15] G. Decher, J. D. Hong, Ber. Bunsen-Ges. 1991, 95, 1430

[16] D. Ingersoll, P. J. Kulesza, L. R. Faulkner, J. Electrochem. Soc. 1994 , 141,140 .

[17] S. Liu, D. Volkmer, D. G. Kurth, J. Cluster Sci. 2003, 14, 405.

[18] N. A. Kotov, I. Dekany, J. H. Fendler, J. Phys. Chem. 1995, 99, 13065 .

[19] A. A. Mamedov, N. A. Kotov, M. Prato, D. M. Guldi, J. P. Wicksted, A. Hirsch, Nat. Mater. 2002, 1, 190.

[20] C. Jiang, H. Ko, V. V. Tsukruk, Adv. Mater. 2005, 17, 2127.

[21] S. W. Keller, H. N. Kim, T. E. Mallouk, J. Am. Chem. Soc. 1994, 116, 8817.

[22] E. R. Kleinfeld, G. S. Ferguson, Science 1994, 265, 370.

[23] T. M. Cooper, A. L. Campbell, R. L. Crane, Langmuir 1995, 11, 2713.

[24] J. A. He, R. Valluzzi, K. Yang, T. Dolukhanyan, C. Sung, J. Kumar, S. K. Tripathy, L. Samuelson, L. Balogh, D. A. Tomalia, Chem. Mater. $\mathbf{1 9 9 9}, 11,3268$

[25] K. Araki, M. J. Wagner, M. S. Wrighton, Langmuir 1996, 12, 5393

[26] Y. Lvov, M. Onda, K. Ariga, T. Kunitake, J. Biomater. Sci. Polym. Ed. 1998, 9, 345

[27] L. Richert, P. Lavalle, D. Vautier, B. Senger, J. F. Stoltz, P. Schaaf, J. C. Voegel, C. Picart, Biomacromolecules 2002, 3, 1170

[28] M. Mueller, Biomacromolecules 2001, 2, 262.

[29] F. Boulmedais, V. Ball, P. Schwinte, B. Frisch, P. Schaaf, J. C. Voegel, Langmuir 2003, 19, 440

[30] Y. Lvov, G. Decher, G. Sukhorukov, Macromolecules 1993, 26, 5396.

[31] J. D. Hong, K. Lowack, J. Schmitt, G. Decher, Prog. Colloid Polym. Sci. 1993, 93, 98.

[32] Y. Lvov, K. Ariga, T. Kunitake, Chem. Lett. 1994, 2323.

[33] Y. Lvov, K. Ariga, I. Ichinose, T. Kunitake, J. Am. Chem. Soc. 1995 , $117,6117$.

[34] W. Kong, X. Zhang, M. L. Gao, H. Zhou, W. Li, J. C. Shen, Macromol. Rapid Commun. 1994, 15, 405

[35] P. J. Yoo, K. T. Nam, J. Qi, S.-K. Lee, J. Park, A. M. Belcher, P. T. Hammond, Nat. Mater. 2006, 5, 234.

[36] W. B. Stockton, M. F. Rubner, Mater. Res. Soc. Symp. Proc. 1995, 369,587

[37] Y. Shimazaki, M. Mitsuishi, S. Ito, M. Yamamoto, Langmuir 1997, $13,1385$.

[38] E. Brynda, M. Houska, J. Colloid Interface Sci. 1996, 183, 18.

[39] J. Sun, T. Wu, Y. Sun, Z. Wang, Z. Xi, J. Shen, W. Cao, Chem. Commun. 1998, 1853.
[40] J. i. Anzai, Y. Kobayashi, N. Nakamura, M. Nishimura, T. Hoshi, Langmuir 1999, 15, 221.

[41] N. A. Kotov, Nanostruct. Mater. 1999, 12, 789.

[42] E. Lojou, P. Bianco, Langmuir 2004, 20, 748.

[43] A. Delcorte, P. Bertrand, E. Wischerhoff, A. Laschewsky, Langmuir 1997, 13, 5125.

[44] Polyelectrolyte Multilayers Home Page. http://www.chem.fsu.edu/ multilayers/ (accessed December, 2005).

[45] J. H. Fendler, Chem. Mater. 1996, 8, 1616.

[46] P. Bertrand, A. Jonas, A. Laschewsky, R. Legras, Macromol. Rapid Commun. 2000, 21, 319.

[47] P. T. Hammond, Curr. Opin. Colloid Interface Sci. 1999, 4, 430.

[48] P. T. Hammond, Adv. Mater. 2004, 16, 1271.

[49] N. A. Kotov, L. M. Liz-Marzan, in Nanoscale Materials (Eds: L. M. Liz-Marzan, P. V. Kamat), Kluwer Academic, Norwell, MA 2003.

[50] Multilayer Thin Films: Sequential Assembly of Nanocomposite Materials (Eds: G. Decher, J. B. Schlenoff), Wiley-VCH, Weinheim, Germany 2003.

[51] H. Ai, S. A. Jones, Y. M. Lvov, Cell Biochem. Biophys. 2003, 39, 23.

[52] M. Campas, C. O'Sullivan, Anal. Lett. 2003, 36, 2551.

[53] J. C. Voegel, G. Decher, P. Schaaf, Actual. Chim. 2003, 30.

[54] Y. M. Lvov, R. R. Price, Colloids Surf. B 2002, 23, 251.

[55] M. T. Crisp, N. A. Kotov, Nano Lett. 2003, 3, 173.

[56] E. Donath, G. B. Sukhorukov, F. Caruso, S. A. Davis, H. Moehwald, Angew. Chem. Int. Ed. 1998, 37, 2202.

[57] F. Caruso, R. A. Caruso, H. Moehwald, Science 1998, 282, 1111.

[58] F. Caruso, Adv. Mater. 2001, 13,11.

[59] G. B. Sukhorukov, H. Moehwald, in Colloids and Colloid Assemblies, (Ed: F. Caruso), Wiley-VCH, Weinheim, Germany 2004, Ch. 18.

[60] Z. Tang, W. Jing, E. Wang, Langmuir 2000, 16, 1696.

[61] K. Katagiri, R. Hamasaki, K. Ariga, J. I. Kikuchi, Langmuir 2002, $18,6709$.

[62] K. Katagiri, R. Hamasaki, K. Ariga, J. I. Kikuchi, J. Am. Chem. Soc. 2002, 124, 7892 .

[63] M. Michel, D. Vautier, J. C. Voegel, P. Schaaf, V. Ball, Langmuir 2004, 20, 4835.

[64] M. Michel, A. Izquierdo, G. Decher, J. C. Voegel, P. Schaaf, V. Ball, Langmuir 2005, 21, 7854.

[65] F. Boulmedais, M. Bozonnet, P. Schwinte, J. C. Voegel, P. Schaaf, Langmuir 2003, 19, 9873.

[66] M. Debreczeny, V. Ball, F. Boulmedais, B. Szalontai, J. C. Voegel, P. Schaaf, J. Phys. Chem. B 2003, 107, 12734.

[67] D. T. Haynie, S. Balkundi, N. Palath, K. Chakravarthula, K. Dave, Langmuir 2004, 20, 4540.

[68] G. B. Sukhorukov, M. M. Montrel, A. I. Petrov, L. I. Shabarchina, B. I. Sukhorukov, Biosens. Bioelectron. 1996, 11, 913.

[69] M. M. Montrel, G. B. Sukhorukov, A. I. Petrov, L. I. Shabarchia, B. I. Sukhorukov, Sens. Actuators, B 1997, 42, 225.

[70] M. Onda, K. Ariga, T. Kunitake, J. Biosci. Bioeng. 1999, 87, 69.

[71] M. Rubner, Nature 2003, 423, 925.

[72] N. A. Kotov, T. Haraszti, L. Turi, G. Zavala, R. E. Geer, I. Dekany, J. H. Fendler, J. Am. Chem. Soc. 1997, 119, 6821

[73] Z. Tang, N. A. Kotov, S. Magonov, B. Ozturk, Nat. Mater. 2003, 2, 413.

[74] P. Podsiadlo, S. Paternel, J. M. Rouillard, Z. Zhang, J. Lee, J. W. Lee, E. Gulari, N. A. Kotov, Langmuir 2005, 21, 11915.

[75] T. Sun, L. Feng, X. Gao, L. Jiang, Acc. Chem. Res. 2005, 38, 644.

[76] T. Soeno, K. Inokuchi, S. Shiratori, Appl. Surf. Sci. 2004, 237, 543.

[77] X. Zhang, F. Shi, X. Yu, H. Liu, Y. Fu, Z. Wang, L. Jiang, X. Li, J. Am. Chem. Soc. 2004, 126, 3064.

[78] F. Shi, Z. Wang, X. Zhang, Adv. Mater. 2005, 17, 1005.

[79] N. Zhao, F. Shi, Z. Wang, X. Zhang, Langmuir 2005, 21, 4713.

[80] S. Sangribsub, P. Tangboriboonrat, T. Pith, G. Decher, Polym. Bull. 2005, 53, 425 . 
[81] R. M. Jisr, H. H. Rmaile, J. B. Schlenoff, Angew. Chem. Int. Ed. $\mathbf{2 0 0 5}, 44,782$.

[82] L. Zhai, F. C. Cebeci, R. E. Cohen, M. F. Rubner, Nano Lett. 2004, 4, 1349.

[83] J. A. He, L. Samuelson, L. Li, J. Kumar, S. K. Tripathy, J. Phys. Chem. B 1998, 102, 7067.

[84] J. A. He, L. Samuelson, L. Li, J. Kumar, S. K. Tripathy, Langmuir 1998, 14, 1674.

[85] J. A. He, L. Samuelson, L. Li, J. Kumar, S. K. Tripathy, Adv. Mater. 1999, 11, 435

[86] M. Li, B. Li, L. Jiang, T. Tussila, N. Tkachenko, H. Lemmetyinen, Langmuir 2000, 16, 5503 .

[87] T. Jussila, M. Li, N. V. Tkachenko, S. Parkkinen, B. Li, L. Jiang, H. Lemmetyinen, Biosens. Bioelectron. 2002, 17, 509.

[88] A. A. Dementiev, A. A. Baikov, V. V. Ptushenko, G. B. Khomutov, A. N. Tikhonov, Biochim. Biophys. Acta 2005, 1712, 9.

[89] D. M. Kaschak, S. A. Johnson, C. C. Waraksa, J. Pogue, T. E. Mallouk, Coord. Chem. Rev. 1999, 185-186, 403.

[90] D. Balbinot, S. Atalick, D. M. Guldi, M. Hatzimarinaki, A. Hirsch, N. Jux, J. Phys. Chem. B 2003, 107, 13273.

[91] I. Zilbermann, A. Lin, M. Hatzimarinaki, A. Hirsch, D. M. Guldi, Chem. Commun. 2004, 96.

[92] J. A. Jaber, P. B. Chase, J. B. Schlenoff, Nano Lett. 2003, 3, 1505.

[93] X. Zu, Z. Lu, Z. Zhang, J. B. Schenkman, J. F. Rusling, Langmuir 1999, 15, 7372 .

[94] Z. Xu, N. Gao, H. Chen, S. Dong, Langmuir 2005, 21, 10808.

[95] A. L. De Lacey, M. Detcheverry, J. Moiroux, C. Bourdillon, Biotechnol. Bioeng. 2000, $68,1$.

[96] G. Decher, B. Lehr, K. Lowack, Y. Lvov, J. Schmitt, Biosens. Bioelectron. 1994, 9, 677.

[97] I. Willner, A. N. Shipway, B. Willner, in Molecules as Components of Electronic Devices (Ed: M. Lieberman), Oxford University Press, New York 2003, Ch. 8.

[98] Y. Sun, X. Zhang, C. Sun, J. Shen, Macromol. Chem. Phys. 1996, 197, 147.

[99] S. Zhang, W. Yang, Y. Niu, C. Sun, Sens. Actuators, B 2004, 101, 387.

[100] J. Hodak, R. Etchenique, E. J. Calvo, K. Singhal, P. N. Bartlett, Langmuir 1997, 13, 2708

[101] E. J. Calvo, R. Etchenique, L. Pietrasanta, A. Wolosiuk, C. Danilowicz, Anal. Chem. 2001, 73, 1161 .

[102] E. J. Calvo, C. Danilowicz, A. Wolosiuk, J. Am. Chem. Soc. 2002, 124,2452

[103] E. J. Calvo, A. Wolosiuk, ChemPhysChem 2004, 5, 235.

[104] S. Hou, J. Wang, C. R. Martin, Nano Lett. 2005, 5, 231.

[105] N. Loew, F. W. Scheller, U. Wollenberger, Electroanalysis 2004, 16 , 1149.

[106] S. I. Suye, H. Zheng, H. Okada, T. Hori, Sens. Actuators, B 2005 , 108,671

[107] K. Sirkar, A. Revzin, M. V. Pishko, Anal. Chem. 2000, 72, 2930.

[108] T. Hoshi, T. Noguchi, J. i. Anzai, New Technol. Med. 2004, 5, 345.

[109] J. J. Xu, W. Zhao, X. L. Luo, H. Y. Chen, Chem. Commun. 2005 792.

[110] E. J. Calvo, F. Battaglini, C. Danilowicz, A. Wolosiuk, M. Otero, Faraday Discuss. 2000, 116, 47.

[111] A. L. Simonian, A. Revzin, J. R. Wild, J. Elkind, M. V. Pishko, Anal. Chim. Acta 2002, 466, 201.

[112] C. Sun, W. Li, Y. Sun, Z. Xi, J. Shen, Electrochim. Acta 1999, 44, 3401.

[113] J. i. Anzai, Y. Kobayashi, Langmuir 2000, 16, 2851.

[114] V. Rosca, I. Catalin Popescu, Electrochem. Commun. 2002, 4, 904

[115] X. Yu, G. A. Sotzing, F. Papadimitrakopoulos, J. F. Rusling, Anal. Chem. 2003, 75, 4565 .

[116] A. Narvaez, G. Suarez, I. C. Popescu, I. Katakis, E. Dominguez, Biosens. Bioelectron. 2000, 15, 43.

[117] E. S. Forzani, V. M. Solis, E. J. Calvo, Anal. Chem. 2000, 72, 5300.
[118] L. Coche-Guerente, P. Labbe, V. Mengeaud, Anal. Chem. 2001, 73, 3206.

[119] L. Coche-Guerente, J. Desbrieres, J. Fatisson, P. Labbe, M. C. Rodriguez, G. Rivas, Electrochim. Acta 2005, 50, 2865.

[120] F. Qu, M. Yang, J. Jiang, G. Shen, R. Yu, Anal. Biochem. 2005, 344, 108.

[121] H. Shi, Z. Song, J. Huang, Y. Yang, Z. Zhao, J. i. Anzai, T. Osa, Q. Chen, Sens. Actuators, B 2005, 109, 341.

[122] M. K. Ram, P. Bertoncello, H. Ding, S. Paddeu, C. Nicolini, Biosens. Bioelectron. 2001, 16, 849.

[123] M. Yang, Y. Yang, H. Yang, G. Shen, R. Yu, Biomaterials 2005, 27, 246.

[124] T. Hoshi, H. Saiki, J. i. Anzai, Talanta 2003, 61, 363.

[125] T. Hoshi, T. Noguchi, J. i. Anzai, Chem. Sens. 2004, 20, 124.

[126] N. Sultana, J. B. Schenkman, J. F. Rusling, J. Am. Chem. Soc. 2005, 127, 13460.

[127] D. S. Patel, R. K. Aithal, G. Krishna, Y. M. Lvov, M. Tien, D. Kuila, Colloids Surf., B 2005, 43, 13.

[128] E. J. Calvo, C. B. Danilowicz, A. Wolosiuk, Phys. Chem. Chem. Phys. 2005, 7, 1800.

[129] Y. Lvov, K. Ariga, I. Ichinose, T. Kunitake, J. Chem. Soc., Chem. Commun. 1995, 2313.

[130] K. Sato, Y. Imoto, J. Sugama, S. Seki, H. Inoue, T. Odagiri, J. i. Anzai, Anal. Sci. 2004, 20, 1247.

[131] K. Sato, Y. Imoto, J. Sugama, S. Seki, H. Inoue, T. Odagiri, T. Hoshi, J. i. Anzai, Langmuir 2005, 21, 797

[132] C. A. Constantine, K. M. Gattas-Asfura, S. V. Mello, G. Crespo, V. Rastogi, T. C. Cheng, J. J. DeFrank, R. M. Leblanc, J. Phys Chem. B 2003, 107, 13762.

[133] C. A. Constantine, S. V. Mello, A. Dupont, X. Cao, D. Santos, Jr., O. N. Oliveira, Jr., F. T. Strixino, E. C. Pereira, T. C. Cheng, J. J. DeFrank, R. M. Leblanc, J. Am. Chem. Soc. 2003, 125, 1805.

[134] S. Disawal, J. Qiu, B. B. Elmore, Y. M. Lvov, Colloids Surf., B 2003, 32,145 .

[135] A. V. Nabok, F. Davis, A. K. Hassan, A. K. Ray, R. Majeed, Z. Ghassemlooy, Mater. Sci. Eng. C 1999, 8-9, 123.

[136] S. R. Forrest, B. B. Elmore, J. D. Palmer, Appl. Biochem. Biotechnol. $\mathbf{2 0 0 5}, 121,85$.

[137] N. Kotov, Nat. Mater. 2004, 3, 669.

[138] C. Jiang, S. Markutsya, Y. Pikus, V. V. Tsukruk, Nat. Mater. 2004, 3 , 721.

[139] X. Yan, H. F. Ji, Y. Lvov, Chem. Phys. Lett. 2004, 396, 34.

[140] X. Yan, X. K. Xu, H. F. Ji, Anal. Chem. 2005, 77, 6197.

[141] F. Caruso, K. Niikura, D. N. Furlong, Y. Okahata, Langmuir 1997, $13,3427$.

[142] E. Brynda, M. Houska, J. Skvor, J. J. Ramsden, Biosens. Bioelectron. 1998, 13, 165 .

[143] E. Brynda, J. Homola, M. Houska, P. Pfeifer, J. Skvor, Sens. Actuators, $B$ 1999, 54, 132.

[144] A. Diederich, M. Losche, Adv. Biophys. 1997, 34, 205.

[145] Y. M. Lvov, Z. Lu, J. B. Schenkman, X. Zu, J. F. Rusling, J. Am. Chem. Soc. 1998, 120, 4073.

[146] B. Munge, C. Estavillo, J. B. Schenkman, J. F. Rusling, ChemBioChem 2003, 4, 82 .

[147] M. K. Beissenhirtz, F. W. Scheller, W. F. M. Stocklein, D. G. Kurth, H. Moehwald, F. Lisdat, Angew. Chem. Int. Ed. 2004, 43, 4357.

[148] M. K. Beissenhirtz, F. W. Scheller, F. Lisdat, Anal. Chem. 2004, 76, 4665.

[149] H. Ma, N. Hu, J. F. Rusling, Langmuir 2000, 16, 4969.

[150] P. He, N. Hu, J. Phys. Chem. B 2004, 108, 13144.

[151] H. Liu, N. Hu, J. Phys. Chem. B 2005, 109, 10464.

[152] J. i. Anzai, N. Nakamura, J. Chem. Soc., Perkin Trans. 2 1999, 2413.

[153] J. i. Anzai, T. Hoshi, N. Nakamura, Langmuir 2000, 16, 6306.

[154] H. Inoue, J. i. Anzai, Langmuir 2005, 21, 8354.

[155] F. Caruso, E. Rodda, D. N. Furlong, K. Niikura, Y. Okahata, Anal. Chem. 1997, 69, 2043 
[156] X. C. Zhou, L. Q. Huang, S. F. Y. Li, Biosens. Bioelectron. 2001, 16, 85.

[157] J. F. Rusling, Biosens. Bioelectron. 2004, 20, 1022.

[158] B. Wang, J. F. Rusling, Anal. Chem. 2003, 75, 4229.

[159] A. Mugweru, B. Wang, J. Rusling, Anal. Chem. 2004, 76, 5557.

[160] S. Liu, D. G. Kurth, D. Volkmer, Chem. Commun. 2002, 976.

[161] S. Liu, D. Volkmer, D. G. Kurth, Anal. Chem. 2004, 76, 4579.

[162] A. Yu, Z. Liang, J. Cho, F. Caruso, Nano Lett. 2003, 3, 1203.

[163] L. Qian, Q. Gao, Y. Song, Z. Li, X. Yang, Sens. Actuators, B 2005 , 107, 303.

[164] M. K. Ram, O. Yavuz, V. Lahsangah, M. Aldissi, Sens. Actuators, B 2005, 106,750 .

[165] D. S. Koktysh, X. Liang, B. G. Yun, I. Pastoriza-Santos, R. L. Matts, M. Giersig, C. Serra-Rodriguez, L. M. Liz-Marzan, N. A. Kotov, Adv. Funct. Mater. 2002, 12, 255.

[166] M. Zhang, K. Gong, H. Zhang, L. Mao, Biosens. Bioelectron. 2005, $20,1270$.

[167] L. Cheng, G. E. Pacey, J. A. Cox, Anal. Chem. 2001, 73, 5607.

[168] P. A. Fiorito, V. R. Goncales, E. A. Ponzio, S. I. Cordoba de Torresi, Chem. Commun. 2005, 366.

[169] T. Hoshi, H. Saiki, S. Kuwazawa, C. Tsuchiya, Q. Chen, J. i. Anzai, Anal. Chem. 2001, 73, 5310.

[170] R. Malaisamy, M. L. Bruening, Langmuir 2005, 21, 10587.

[171] H. H. Rmaile, J. B. Schlenoff, J. Am. Chem. Soc. 2003, 125, 6602.

[172] M. W. Kamande, X. Zhu, C. Kapnissi-Christodoulou, I. M. Warner, Anal. Chem. 2004, 76, 6681 .

[173] Controlled Release of Biologically Active Agents (Ed: R. Baker), $\mathrm{VCH}$, Weinheim, Germany 1987.

[174] K. E. Uhrich, S. M. Cannizzaro, R. S. Langer, K. M. Shakesheff, Chem. Rev. 1999, 99, 3181.

[175] A. J. Chung, M. F. Rubner, Langmuir 2002, 18, 1176

[176] S. E. Burke, C. J. Barrett, Macromolecules 2004, 37, 5375.

[177] M. Mueller, B. Kessler, H. J. Adler, K. Lunkwitz, Macromol. Symp. 2004, 210, 157.

[178] S. Jiang, X. Chen, M. Liu, J. Colloid Interface Sci. 2004, 277, 396.

[179] K. C. Wood, J. Q. Boedicker, D. M. Lynn, P. T. Hammond, Langmuir 2005, 21, 1603.

[180] S. T. Dubas, T. R. Farhat, J. B. Schlenoff, J. Am. Chem. Soc. 2001, 123, 5368 .

[181] V. A. Izumrudov, E. Kharlampieva, S. A. Sukhishvili, Biomacromolecules 2005, 6, 1782 .

[182] S. A. Sukhishvili, S. Granick, J. Am. Chem. Soc. 2000, 122, 9550.

[183] T. W. Healy, L. R. White, Adv. Colloid Interface Sci. 1978, 9, 303.

[184] F. Yamauchi, K. Kato, H. Iwata, Langmuir 2005, 21, 8360.

[185] N. A. Peppas, R. Langer, Science 1994, 263, 1715.

[186] N. A. Peppas, Y. Huang, M. Torres-Lugo, J. H. Ward, J. Zhang, Annu. Rev. Biomed. Eng. 2000, 2, 9.

[187] Y. Kaneko, S. Nakamura, K. Sakai, T. Aoyagi, A. Kikuchi, Y. Sakurai, T. Okano, Macromolecules 1998, 31, 6099.

[188] J. F. Quinn, F. Caruso, Langmuir 2004, 20, 20.

[189] J. F. Quinn, F. Caruso, Macromolecules 2005, 38, 3414

[190] C. M. Nolan, M. J. Serpe, L. A. Lyon, Biomacromolecules 2004, 5 , 1940.

[191] A. W. Jensen, N. K. Desai, B. S. Maru, D. K. Mohanty, Macromolecules 2004, 37, 4196.

[192] T. Groth, A. Lendlein, Angew. Chem. Int. Ed. 2004, 43, 926.

[193] E. Vazquez, D. M. Dewitt, P. T. Hammond, D. M. Lynn, J. Am. Chem. Soc. 2002, 124, 13992.

[194] J. Zhang, L. S. Chua, D. M. Lynn, Langmuir 2004, 20, 8015.

[195] B. Thierry, P. Kujawa, C. Tkaczyk, F. M. Winnik, L. Bilodeau, M. Tabrizian, J. Am. Chem. Soc. 2005, 127, 1626.

[196] T. Serizawa, M. Yamaguchi, M. Akashi, Biomacromolecules 2002, 3, 724.

[197] T. Serizawa, M. Yamaguchi, M. Akashi, Angew. Chem. Int. Ed. 2003 , $42,1115$.
[198] T. Serizawa, H. Goto, A. Kishida, T. Endo, M. Akashi, J. Polym. Sci., Part A: Polym. Chem. 1999, 37, 801.

[199] V. S. Trubetskoy, A. Loomis, J. E. Hagstrom, V. G. Budker, J. A Wolff, Nucleic Acids Res. 1999, 27, 3090.

[200] D. S. Salloum, J. B. Schlenoff, Biomacromolecules 2004, 5, 1089

[201] C. Gergely, S. Bahi, B. Szalontai, H. Flores, P. Schaaf, J. C. Voegel, F. J. G. Cuisinier, Langmuir 2004, 20, 5575.

[202] K. I. Hamada, K. Yamashita, T. Serizawa, T. Kitayama, M. Akashi, J. Polym. Sci., Part A: Polym. Chem. 2003, 41, 1807.

[203] G. Ladam, P. Schaaf, F. J. G. Cuisinier, G. Decher, J. C. Voegel, Langmuir 2001, 17, 878.

[204] G. Ladam, P. Schaaf, G. Decher, J. C. Voegel, F. J. G. Cuisinier, Biomol. Eng. 2002, 19, 273

[205] M. Muller, T. Rieser, P. L. Dubin, K. Lunkwitz, Macromol. Rapid Commun. 2001, 22, 390.

[206] P. Schwinte, V. Ball, B. Szalontai, Y. Haikel, J. C. Voegel, P. Schaaf, Biomacromolecules 2002, 3, 1135.

[207] L. Szyk, P. Schaaf, C. Gergely, J. C. Voegel, B. Tinland, Langmuir 2001, 17, 6248.

[208] L. Szyk, P. Schwinte, J. C. Voegel, P. Schaaf, B. Tinland, J. Phys. Chem. B 2002, 106, 6049.

[209] C. Boura, P. Menu, E. Payan, C. Picart, J. C. Voegel, S. Muller, J. F. Stoltz, Biomaterials 2003, 24, 3521.

[210] M. K. Gheith, V. A. Sinani, J. P. Wicksted, R. L. Matts, N. A. Kotov, Adv. Mater. 2005, 17, 2663

[211] Y. Zhu, Y. Sun, Colloids Surf., B 2004, 36, 49.

[212] H. Zhu, J. Ji, J. Shen, Biomaterials 2003, 25, 109.

[213] H. Ai, Y. M. Lvov, D. K. Mills, M. Jennings, J. S. Alexander, S. A. Jones, Cell Biochem. Biophys. 2003, 38, 103.

[214] J. D. Glawe, J. B. Hill, D. K. Mills, M. J. McShane, J. Biomed. Mater. Res., Part $A$ 2005, 75, 106 .

[215] H. Zhu, J. Ji, J. Shen, Biomacromolecules 2004, 5, 1933.

[216] X. Liu, L. Smith, G. Wei, Y. Won, P. X. Ma, J. Biomed. Nanotechnol. $\mathbf{2 0 0 5}, 1,54$.

[217] J. Lee, S. Shanbhag, N. A. Kotov, J. Mater. Chem. 2006, 16, 3558.

[218] V. A. Sinani, D. S. Koktysh, B. G. Yun, R. L. Matts, T. C. Pappas, M. Motamedi, S. N. Thomas, N. A. Kotov, Nano Lett. 2003, 3, 1177.

[219] S. G. Olenych, M. D. Moussallem, D. S. Salloum, J. B. Schlenoff, T. C. S. Keller, Biomacromolecules 2005, 6, 3252.

[220] E. Brynda, J. Pachernik, M. Houska, Z. Pientka, P. Dvorak, Langmuir 2005, 21, 7877 .

[221] M. R. Kreke, A. S. Badami, J. B. Brady, R. M. Akers, A. S. Goldstein, Biomaterials 2005, 26, 2975.

[222] N. Jessel, F. Atalar, P. Lavalle, J. Mutterer, G. Decher, P. Schaaf, J. C. Voegel, J. Ogier, Adv. Mater. 2003, 15, 692.

[223] S. K. Hahn, A. S. Hoffman, Biotechnol. Bioprocess Eng. 2004, 9, 179.

[224] J. J. Hwang, S. Jelacic, N. T. Samuel, R. V. Maier, C. T. Campbell, D. G. Castner, A. S. Hoffman, P. S. Stayton, J. Biomater. Sci., Polym. Ed. 2005, 16, 237.

[225] A. J. Engler, L. Richert, J. Y. Wong, C. Picart, D. E. Discher, Surf. Sci. 2004, 570, 142.

[226] J. D. Mendelsohn, S. Y. Yang, J. Hiller, A. I. Hochbaum, M. F. Rubner, Biomacromolecules 2003, 4, 96.

[227] S. Y. Yang, J. D. Mendelsohn, M. F. Rubner, Biomacromolecules $\mathbf{2 0 0 3}, 4,987$

[228] L. Richert, Y. Arntz, P. Schaaf, J. C. Voegel, C. Picart, Surf. Sci. 2004, $570,13$.

[229] S. S. Shiratori, M. F. Rubner, Macromolecules 2000, 33, 4213.

[230] M. C. Berg, S. Y. Yang, P. T. Hammond, M. F. Rubner, Langmuir 2004, 20, 1362.

[231] J. S. Mohammed, M. A. DeCoster, M. J. McShane, Biomacromolecules 2004, 5, 1745 .

[232] D. R. Reyes, E. M. Perruccio, S. P. Becerra, L. E. Locascio, M. Gaitan, Langmuir 2004, 20, 8805. 
[233] H. Zheng, M. C. Berg, M. F. Rubner, P. T. Hammond, Langmuir 2004, 20, 7215.

[234] P. Schaaf, J. C. Voegel, Pathol. Biol. 2002, 50, 189.

[235] C. Boura, S. Muller, D. Vautier, D. Dumas, P. Schaaf, J. C. Voegel, J. F. Stoltz, P. Menu, Biomaterials 2005, 26, 4568.

[236] C. Boura, S. Muller, J. C. Voegel, P. Schaaf, J. F. Stoltz, P. Menu, Clin. Hemorheol. Microcirc. 2005, 33, 269.

[237] Y. Zhu, C. Gao, Y. Liu, J. Shen, J. Biomed. Mater. Res., Part A 2004, $69,436$.

[238] P. Tryoen-Toth, D. Vautier, Y. Haikel, J. C. Voegel, P. Schaaf, J. Chluba, J. Ogier, J. Biomed. Mater. Res. 2002, 60, 657.

[239] H. Zhu, J. Ji, M. A. Barbosa, J. Shen, J. Biomed. Mater. Res., Part B 2004, 71,159

[240] S. Liao, W. Wang, M. Uo, S. Ohkawa, T. Akasaka, K. Tamura, F. Cui, F. Watari, Biomaterials 2005, 26, 7564.

[241] J. Chluba, J. C. Voegel, G. Decher, P. Erbacher, P. Schaaf, J. Ogier, Biomacromolecules 2001, 2, 800.

[242] D. Vautier, V. Karsten, C. Egles, J. Chluba, P. Schaaf, J. C. Voegel, J. Ogier, J. Biomater. Sci., Polym. Ed. 2002, 13, 713.

[243] Z. Mao, L. Ma, J. Zhou, C. Gao, J. Shen, Bioconjugate Chem. 2005 $16,1316$.

[244] D. L. Elbert, C. B. Herbert, J. A. Hubbell, Langmuir 1999, 15, 5355.

[245] A. Khademhosseini, S. Jon, K. Y. Suh, T. N. Tran, G. Eng, J. Yeh, J. Seong, R. Langer, Adv. Mater. 2003, 15, 1995.

[246] A. Khademhosseini, K. Y. Suh, J. M. Yang, G. Eng, J. Yeh, S. Levenberg, R. Langer, Biomaterials 2004, 25, 3583.

[247] J. Fukuda, A. Khademhosseini, J. Yeh, G. Eng, J. Cheng, O. C. Farokhzad, R. Langer, Biomaterials 2006, 27, 1479.

[248] M. Houska, E. Brynda, J. Colloid Interface Sci. 1997, 188, 243.

[249] J. Ji, Q. Tan, J. Shen, Polym. Adv. Technol. 2004, 15, 490.

[250] Q. Tan, J. Ji, F. Zhao, D. Z. Fan, F. Y. Sun, J. C. Shen, J. Mater. Sci. Mater. Med. 2005, 16, 687 .

[251] J. Ji, Q. Tan, D. Z. Fan, F. Y. Sun, M. A. Barbosa, J. Shen, Colloids Surf., $B$ 2004, 34, 185.

[252] J. Fu, J. Ji, W. Yuan, J. Shen, Biomaterials 2005, 26, 6684
[253] Q. Tan, J. Ji, M. A. Barbosa, C. Fonseca, J. Shen, Biomaterials 2003, $24,4699$.

[254] H. Sakaguchi, T. Serizawa, M. Akashi, Chem. Lett. 2003, 174.

[255] K. Cai, A. Rechtenbach, J. Hao, J. Bossert, K. D. Jandt, Biomaterials 2005, 26, 5960 .

[256] B. Thierry, F. M. Winnik, Y. Merhi, J. Silver, M. Tabrizian, Biomacromolecules $\mathbf{2 0 0 3}, 4,1564$.

[257] M. C. Chen, H. F. Liang, Y. L. Chiu, Y. Chang, H. J. Wei, H. W. Sung, J. Controlled Release 2005, 108, 178.

[258] N. Benkirane-Jessel, P. Schwinte, P. Falvey, R. Darcy, Y. Haikel, P. Schaaf, J. C. Voegel, J. Ogier, Adv. Funct. Mater. 2004, 14, 174.

[259] N. Benkirane-Jessel, P. Lavalle, F. Meyer, F. Audouin, B. Frisch, P. Schaaf, J. Ogier, G. Decher, J. C. Voegel, Adv. Mater. 2004, 16, 1507.

[260] L. Richert, P. Lavalle, E. Payan, X. Z. Shu, G. D. Prestwich, J. F. Stoltz, P. Schaaf, J. C. Voegel, C. Picart, Langmuir 2004, 20, 448

[261] F. Boulmedais, B. Frisch, O. Etienne, P. Lavalle, C. Picart, J. Ogier, J. C. Voegel, P. Schaaf, C. Egles, Biomaterials 2004, 25, 2003.

[262] O. Etienne, C. Picart, C. Taddei, Y. Haikel, J. L. Dimarcq, P. Schaaf, J. C. Voegel, J. A. Ogier, C. Egles, Antimicrob. Agents Chemother 2004, $48,3662$.

[263] O. Etienne, C. Gasnier, C. Taddei, J. C. Voegel, D. Aunis, P. Schaaf, M. H. Metz-Boutigue, A. L. Bolcato-Bellemin, C. Egles, Biomaterials $\mathbf{2 0 0 5}, 26,6704$

[264] A. B. G. Lansdown, J. Wound Care 2002, 11, 125.

[265] J. C. Grunlan, J. K. Choi, A. Lin, Biomacromolecules 2005, 6, 1149.

[266] D. Lee, R. E. Cohen, M. F. Rubner, Langmuir 2005, 21, 9651.

[267] T. Chen, K. A. Friedman, I. Lei, A. Heller, Anal. Chem. 2000, 72, 3757.

[268] I. Galeska, T. Hickey, F. Moussy, D. Kreutzer, F. Papadimitrakopoulos, Biomacromolecules 2001, 2, 1249.

[269] W. He, R. V. Bellamkonda, Biomaterials 2005, 26, 2983.

[270] B. Thierry, F. M. Winnik, Y. Merhi, M. Tabrizian, J. Am. Chem. Soc. 2003, 125,7494 